\title{
3000 Area Phase I Environmental Assessment
}

D. G. Ranade

L. D. Kamberg

Date Published

September 1995

Prepared for the U.S. Department of Energy

Assistant Secretary for Environmental Management

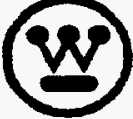

Menegement and Operations Contractor for the

U.S. Depertment of Energy under Contract DE-AC06-87RL 10930

Approved for public release 


\section{DISCLAMMER}

Portions of this document may be illegible in electronic image products. Images are produced from the best available original document. 


\section{RELEASE AUTHORIZATION}

Document Number: $\quad$ WHC-SP-1167

Document Title: $\quad 3000$ Area Phase I Environmental Assessment

Release Date: $\quad$ September 22, 1995

This document was reviewed following the procedures described in WHC-CM-3-4 and is:

APPROVED FOR PUBLIC RELEASE

WHC Information Release Administration Specialist: 
TABLE OF CONTENTS

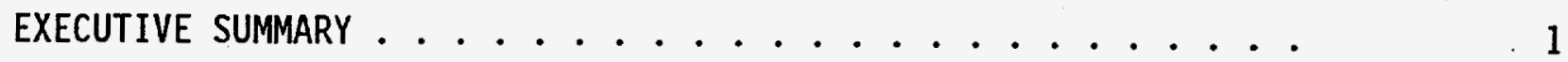

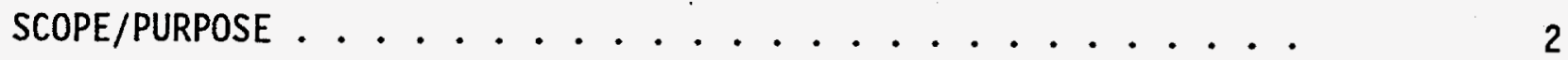

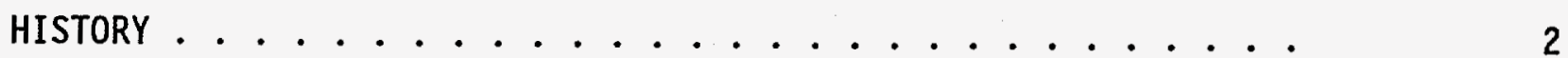

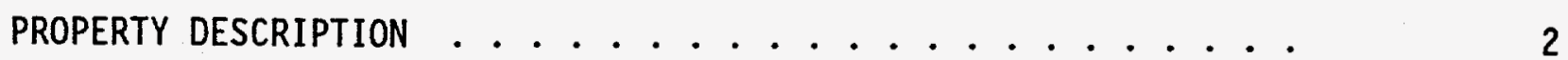

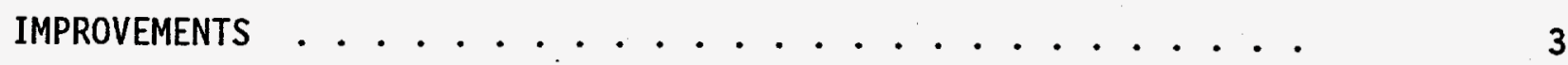

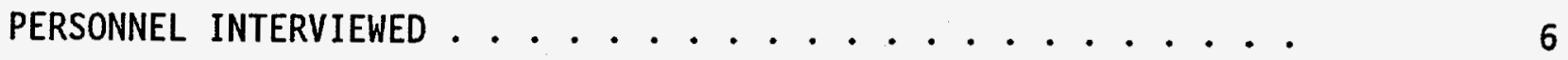

ENVIRONMENTAL CONDITIONS/IMPACTS .............. 8

USTS REMOVED BY WHC AND ICF KH ................ 13

ENVIRONMENTAL CONDITIONS IDENTIFIED DURING THE ASSESSMENT . . . 15

RECOMMENDATIONS ........................ 17 


\section{LIST OF PHOTOGRAPHS}

\section{Photograph}

1 Soil removed from Building 1240 Suspect $0 i 1$ Spill area . . . . . 19

2 Soil removed from Building 1240 French Drain . . . . . . . . 20

3. Satellite Accumulation Area at Building $1226 \ldots 21$

$4 \quad 1234$ Simulated High-Level Waste S7urry Treatment \& Storage Yard . 22

$5 \quad 1235$ Bottle Dock .................. 23

6 Dirt Mound in the southwest corner of the 3000 Area . . . . . . 24

7 Soil pile on the northeast of Building $1208 \ldots \ldots 25$

8 Railroad ties in the southeast part of the 3000 Area . . . . . 26

9 Damaged ACM on kitchen area pipe elbow in Building 1256 . . . . 27

10 Thermal pipe insulation in poor condition above the ceiling in

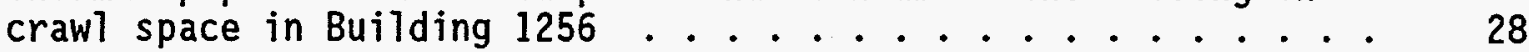

11 Thermal pipe insulation in fair condition, just inside the entry in Building $1154 \ldots \ldots . \ldots . \ldots 29$

12 Duct work with insulation in good condition, outside north end of Building $1256 \ldots \ldots 30$

13 Thermal pipe insulation in fair condition in the Compressor

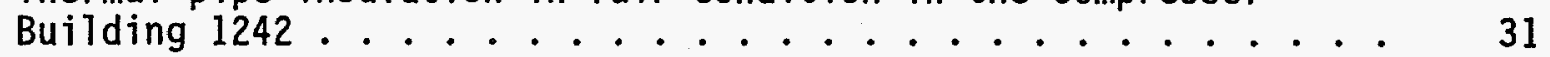

141208 Sandblast Area . . . . . . . . . . . . 32

15 Machine pit filled with oil stained soil. Drain grate outline is 33 visible in the center of the picture ...........

$170 i 1$ stained concrete floor in the compressor room, Building $1226 \quad 35$

18 0il leaking through siding of compressor room, Building 1226 . . 36

19 Typical damaged cement asbestos board siding at Building 1226 . . 37

$200 i 1$ stained ground outside the west side of Building $1242 \ldots 38$

21 Above-ground tank on the east side of Building $1242 \ldots 39$

22 JA Jones Steam Plant location at north end of propeity showing the

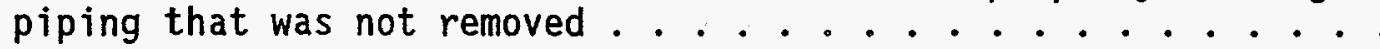


WHC-SP-1167

Rev. 0

\section{LIST OF FIGURES}

\section{Figure}

Page

11948 Aerial Map of 3000 area . . . . . . . . . . . . 41

21990 Aerial Map of 3000 Area . . . . . . . . . . 42

3 Location of WMUs in Operable unit 1100-EM-3 . . . . . . . 43

41262 Building showing location of USTs .......... 44

5 tocation of USTs removed by WHC/ICF KH .......... 45 
WHC-SP-1167

Rev. 0

This page intentionally left blank. 


\section{EXECUTIVE SUMMARY}

The U.S. Department of Energy (DOE) is planning to sell the 3000 Area to prospective buyers. Environmental Services was requested by the WHC Economic Transition group to assess potential environmental liabilities in the area.

Historical review of the area indicated that the site was the location of "Camp Hanford" in 1951 and has been used for a variety of purposes since then. The activities in the area have changed over the years. A number of Buildings from the area have been demolished and at least 15 underground storage tanks (USTs) have been removed.

Part of the 3000 Area was identified as Operable Unit 1100-EM-3 in the TriParty Agreement and was cleaned up by the U.S. Army Corps of Engineers (USACE). The cleanup included removal of contaminated soil and USTs. WHC and ICF KH had also performed sampling and analysis at some locations in the 3000 Area prior to USACE's work on the Operable Unit 1100-EM-3. They removed a number of USTs and performed remediation.

A number of potential environmental problems were found in several locations. Some of these are described below:

Building 1208 had a spray paint booth which was removed about four years ago. Two floor drains are located near the vicinity of the former location of the paint booth. Both of these drains discharge to the soil columns. Paint residues may have been washed into the soil column during the spray painting operations.

Building 1218 was 7 isted as a service station in the old drawings but no record of an UST location could be found. There is no record of UST removal either.

Numerous oil stained spots were observed around Building 1226. The oil stains were a result of vehicle and construction equipment being parked at the location over a number of years. There is an add-on compressor room attached to the Building on the east side. Significant oil staining of the concrete floor is visible. Also oil stains were noted on the exterior walls of the compressor room.

On the north side of Building 1240 is an approximately 1.22 meters $\times 2.44$ meters (4 feet $\times 10$ feet) concrete 1 ined pit with what appears to be a sump grate in the northeast corner. There used to be a Wallace 6" pipe bender machine at this location. The pit contains oily stained soil.

Building 1242 houses a compressor that was used for sandblasting. There is a considerable amount of oil staining both inside and outside the building.

Building 1241 has a trench containing oil left from a plate shear machine.

Asbestos containing materials (ACM) were reported to be present in the form of caulking material, insulation, siding and vinyl floor tiles in Buildings 1154, $1209,1240,1241,1242,1252,1256,1262$. 


\section{SCOPE/PURPOSE}

The assessment was requested by the Economic Transition Group of WHC. The purpose of the assessment was to identify any potential environmentai liabilities for DOE. This was accomplished by conducting an environmental assessment of the area and identifying existing or potential environmental non-compliant conditions.

The scope of the assessment was limited to interviews, document and historical reviews as well as field visits.

\section{HISTORY}

Prior to 1943, the 3000 Area was originally used for agricultural related activities. A water supply ditch, still visible at the northern boundary of the 3000 Area, most probably supplied farms surrounding Fruitvale, a former town located near the vicinity at the time.

In 1943, temporary office buildings supported construction and engineering activities and the newly formed Hanford Site began to be constructed at the 3000 Area. This site was part of "Camp Hanford" a larger military camp, that contained automotive repair and maintenance shops, gasoline storage and dispensing stations, artillery repair and maintenance shops, laundry, dry cleaning, cold storage, warehouses, bakery, troop barracks, and administrative buildings. Throughout the 1940's, the 3000 Area was used for office spaces and as an off-loading and warehousing area for construction supplies brought in on the Atomic Energy Commission-Hanford Works Railroad. A 1948 aerial map of the 3000 Area is shown in Figure 1.

By 1951, most of the temporary buildings within the 3000 Area were either removed or demolished, and replaced by permanent structures, many of which still exist today. In 1961, the site was assigned to a construction services company to support construction of the Fast Flux Test Facility.

Current and recent activities at the 3000 Area include painting and sandblasting operations, vehicle maintenance and repair, hazardous material storage, Less Than 90 Day Hazardous Waste Accumulation Areas, warehousing, fabrication shops, radio maintenance, radiography, and research administrative offices.

\section{PROPERTY DESCRIPTION}

The 3000 Area is part of the 1,451 square kilometers (560 Square miles) Hanford Site operated by the DOE in southeastern Washington State. The area includes a 29 hectare fenced in parcel located within the City of Richland and located immediately west of the City of Richland's water supply recharge basins. The property is a portion of the West half of Section 26, Township 10 North, Range 28 East of the Willamete Meridian. Access to the 3000 Area is off of Stevens Drive via Stone Street and lst Street. The area is about 8 kilometers (5 miles) north of Richland City Center.

The 3000 Area includes buildings, mobile offices, remnants of demolished buildings, fenced and open areas. Figure 2 is an aerial map from 1990 showing locations of buildings in the 3000 Area. 
Rev. 0

\section{IMPROVEMENTS}

\section{Building 1154 (Radio Maintenance Building)}

Building 1154 is located in the southwest portion of the 3000 Area, on the west side of "W" Avenue, towards its southerly termination. It is a single story, concrete block and wood structure, approximately 744 square meters ( 8000 square feet) office building with a shop facility. It was originally constructed by the U.S. Army in 1951 to serve as a SignaT Corps maintenance shop. A single wide trailer 48 square meters (520 square feet) is attached to the building. There are six mobile trailers located north of Building 1154 which are used to provide office and work space. The six trailers are:

$\begin{array}{ll}-\quad & M 0-236 \\ -\quad & M 0-237 \\ -\quad & M 0-417 \\ -\quad & M 0-905 \\ -\quad & M 0-906 \\ -\quad & M 0-917\end{array}$

\section{Building 1208}

Building 1208 is located in the southeast portion of the 3000 Area. It is a 186 square meters (2000 square feet) facility constructed in 1978 and recently used for spray painting. It is a metal structure on a concrete foundation and has an office, a storage room and a room where a painting booth was located. The location just north of the building was used for sandblasting.

\section{Butilding 1209 (Radiography Buitiding)}

This is an 85 square meters (910 square feet), single story metal structure with a concrete shielding wall in the center of the building. It was constructed in 1981. The facility is used to X-ray welds. The shielding wall separates a vault and storage area from the darkroom, reading room and offices. The building is also equipped with an in-floor shielded repository for the X-ray source. Additional shielding is provided by movable lead panels.

\section{Building 1226}

Building 1226 is located in the southeast portion of the 3000 Area, on the west side of "U" Avenue, towards its southerly termination. It was constructed in 1951 and is a single story, wood structure with 923 square meters $(9,925$ square feet) of floor space. The building is used as a vehicle maintenance shop. Heavy construction vehicles are parked outside of the building. 


\section{Building 1235/Bottle Dock}

This building is a raised concrete dock with a metal cover. It provides 70 square meters (756 square feet) of storage space. The north part of the structure is used to store bottled gases for construction activities. Currently, the facility and adjacent laydown area are used by ICF KH as a Less Than 90 Day Hazardous Waste Accumulation Area.

\section{Building 1240}

Building 1240 is located at 2701 " $U$ " Avenue in the 3000 Area. The building has been a warehouse/industrial building. It is currently unoccupied. The predominant building is rectangular shaped.

\section{Building 1241}

This building is attached to Building 1240. It is a single story, wood structure with a concrete floor. It was constructed in 1967 and has 569 square meters $(6,120$ square feet) of floor space. It was used as a plate shop. The cold rolling plate machines are housed in the building. The building is not currently occupied.

\section{Building 1242}

It is a single story wood structure with about 89 square meters (960 square feet) of floor space. It was built in 1967 and houses a compressor which is no longer used. The building is divided into two parts. The northern portion is used for storage and the southern portion houses the compressor.

\section{Building 1252}

Building 1252 is located at 2770 " $W$ " Avenue. The building contains approximately 1,373 square meters $(14,700$ square feet). In addition, there are interior partition walls and a fenced interior storage area. The building was used as a receiving and distribution center.

\section{Building 1253}

This is a single story metal structure on a concrete foundation with about 125 square meters (1,330 square feet) of floor space. It is used as a storage area for flammable materials by ICF KH.

\section{Building 1256}

Building 1256 is located at 2765 "U" Avenue. It is a single story wood structure with 957 square meters $(10,292$ square feet) of floor space. The building was previously used as an office building and has just recently been vacated.

\section{Building 1262}

Building 1262 is located at 2770 "U" Avenue. It is basically rectangular shaped building with 522 square meters $(5,618$ square feet) of floor space. It is of wood frame construction, and has a concrete slab foundation. It was originally constructed by the U.S. Army in 1951 as a dry cleaning plant. 


\section{Building 1264}

Building 1264 is located just north of Building 1262. It is an office building, rectangular in shape, with a total gross building area of about 837 square meters ( 9000 square feet). It is of wood frame construction, with a concrete foundation.

Building 1301

Building 1301 is located at 2780 "U" Avenue. It was constructed as an office building in 1980 with 286 square meters $(3,072$ square feet) of floor space. It is a slab-on grade metal structure.

\section{Mobile offices}

There are seven mobile trailer offices located south of Building 1262. The seven trailers are:

- M0369 is a double wide trailer.

- M0846 is a double wide trailer.

- M0561 is a double wide trailer.

- M0850 is a four wide trailer

- M0851 is a double wide trailer.

- M0969 is a tripie wide trailer.

- M0396 is a single wide trailer.

There are a number of smaller trailers located in the southern part of the 3000 Area. There are number of locations where the buildings were either demolished or burned down. Only foundations are present at these locations. There is a mound of dirt in the southwest corner of the 3000 Area. Some loose pieces of equipment are scattered within the mound. 
WHC-SP-1167

Rev. 0

\section{PERSONNEL INTERVIEWED}

The following people were interviewed either in person or via telephone:

Dan Batchelder of Boeing Computer Services (BCS) gave a tour of Building 1154 and provided information and referrals.

Mike GiTbert of BCS gave information on the pipe chase containing ACM and general information about the 3000 Area. He identified locations of Buildings 1207 and 1218 . He remembered that there were underground and above-ground storage tanks at that location. He further stated that the soil in the mound at the southwest corner came from excavation of USTs from the vicinity of Building 1207.

Roger Carpenter of Bechtel Hanford Company (BHI) provided historical information on the 3000 Area. He shared a number of historical maps and identified structures on the maps.

Ron Shuck of BHI provided information and referrals on USTs that were removed by ICF KH and WHC.

Scott Thoren of BHI provided access to BHI files on USTs that were removed by ICF KH and WHC.

Grant Brazil of ICF KH provided information and referrals on 3000 Area.

Tom Brown of ICF KH provided information and referrals on 3000 Area.

Curt Clement of ICF KH served as 3000 Area escort and provided general information on area and environmental studies performed by ICF KH in the 3000 Area.

Chip Conselman of ICF KH provided information and referrals on 3000 Area.

Brian Dixon of ICF KH gave general information on 3000 Area and environmental studies performed by ICF KH in the 3000 Area.

Charles Dohrer of ICF KH provided information and referrals on 3000 Area.

Mike Douglas of ICF KH provided information on 3000 Area USTs that were removed by ICF KH and WHC.

Ron Ingram of ICF KH provided information on USTs in 3000 Area including 1218 service station.

Jeff Kolb of ICF KH gave a tour of Building 1209 and provided information and referrals. 
Jim Lilly of ICF KH provided information on the paint booth in Building 1208. He also gave information on the Satellite Accumulation Area and the Flammable Storage Area located outside the building.

Art MCDaniel of ICF KH provided information on Buildings 1218 and 1226.

Janice Morgan of ICF KH provided historical maps of the 3000 Area.

John Schumacher of ICF KH provided information on Building 1240.

Brad Scott of ICF KH served as Building 1226 escort and provided general information on the building.

Jim Sims of ICF KH was a shop manager for Building 1240 . He gave information on the machines left behind in Building 1241 and a pit area located northeast of Building 1240.

Clark Stolle of ICF KH provided information and referrals on USTs in the 3000 Area.

Bob Urquardt of ICF KH provided information on Building 1208 . He was also very familiar with Building 1242. He explained the operation of the compressor located in the building and the above-ground tank system designed to trap air exhaust from the compressor.

Randy Chong of USACE provided information and documentation on Corps work in the 3000 Area.

Glen Goldberg of DOE provided information and documentation on USACE's work in the 3000 Area.

Michele Gerber of WHC provided historical information on 3000 Area

Tim Orsborn of WHC Radiation Protection Technician gave input on Radiation Survey done for Building 1209.

Richard Roos of WHC Hanford Technical Services provided information and referrals on USTs in 3000 Area. 
WHC-SP-1167

Rev. 0

\section{ENVIRONMENTAL CONDITIONS/IMPACTS}

In May 1989, Department of Energy (DOE), U.S. Environmental Protection Agency (EPA) and Washington State Department of Ecology (WDOE) signed an agreement entitled "Hanford Federal Facility Agreement and Consent Order," commonly referred to as Tri-Party Agreement. One of the stipulations of the agreement was for DOE to prepare an action plan to clean up operable units. The 3000 Area was identified as Operable Unit 1100-EM-3. Operable Unit 1100-EM-3 included a number of Waste Management Units (WMUs) (Figure 3). The USACE was contracted to clean up these operable units.

The area was first surveyed by the USACE to identify WMUs in the Operable Unit 1100-EM-3. The WMUs were classified in one of four categories:

1. Already remediated or currently under regulation by the State or EPA under a statute other than the Comprehensive Environmental Response, Compensation, and Liability Act (CERCLA) or the Model Toxics Control Act (MTCA).

2. Pending or candidate for regulation by the State or EPA under a statute other than CERCLA or MTCA.

3. Not a candidate for regulation under another statute and is the site of a likely or potential release or spill of contaminants to the environment.

4. Not a candidate for regulation under another statute and is the site of a known release or spill of contaminants to the environment.

The WMUs placed under the first category were not evaluated by USACE. WMUs placed under categories $2,3 \& 4$ were evaluated by USACE. Their work is documented in a report entitled Draft Limited Field Investigation/Focused Feasibility Study for the 1100-EM-2, 1100-EM-3, and 1100-IU-1 operable units. Hanford (DOE/RL-92-67). However, it was determined that not every site needed to be cleaned up. Only those sites which exceeded Record of Decision (ROD) cleanup goals were cleaned up. The USACE also removed two USTs which were located in the vicinity of Building 1262 .

The USACE identified the following WMUs as belonging to category 1 in their report, DOE/RL-92-67.

1. 1208 Hazardous Waste Staging Area (HWSA)

2. 1226 HWSA

3. 1240 HWSA

4. $\quad 1234$ Simulated High-Level Waste Slurry Treatment \& Storage Yard

5. Twelve UST Removal/Closure Sites. (Fig. 5) 
WHC-SP-1167

Rev. 0

6. 1235 Bottle Dock

7. 1240 Compressor 0il Spill Area

8. J A Jones Yard HWSA

9. Unplanned Release of Mixed Waste

10. Dirt Mound in the southwest corner of the 3000 Area

11. 1212 Bottle Dock.

12. 3000-12 UST (Fig. 5)

Category 2 WMU

13. 1208 Sandblast Area

Category $3 \& 4$

14. 1240 Suspect Spil1 Area

15. J A Jones 0il Storage Tanks (2)

16. 1262 Transformer Pad.

17. 1262 Solvent Tanks (4)

18. 1240 French Drain.

19. 1226 Suspect Waste 0il Disposal Area

20. J A Jones Steam Plant Drain Pad

21. 1218 Service Station

22. 1212/1227 Suspected Battery Acid Disposal Area

The USACE did not select the 1208 sandblast area because it was not a past practice unit. The remaining eight WMUs from category $3 \& 4$ were further evaluated. The WDOE issued a Record of Decision (ROD) for the 1100-EM-3 Operable Unit. Based on the ROD, and field investigations, the following three WMUs were selected for remediation.

\section{Suspect Spill Area}

USACE has completed remediation at this location. The Soil that was removed is piled up on the south of Building 1240 (Photograph 1).

\section{French Drain}

USACE has completed remediation at this location. The Soil that was removed is piled up on the west of Building 1240 (Photograph 2).

\section{Solvent Tanks}

Drawing \# 36-04-35 shows three tanks located on the southeast side of the Building 1262 (Figure 4). There is one tank (D-25) located inside the building. The information on the tanks is as follows:

Extractor Tank D-25 20 gal

Extractor Tank D-26 100 gal 
Dirty Solvent Tank D-32 1125 gal

Clean Solvent Tank D-32 1125 gal

USACE removed only two tanks from around the Building 1262. During Ground Penetrating Radar (GPR) studies USACE located only two tanks. They assumed that one extractor tank, D-26, was already removed as the tank was shown on Drawing \# 36-04-35 but could not be located by GPR studies. The other extractor tank (D-25), which had a volume of only 76 liters (20 gallons) and located indoors, was probably an above-ground tank.

WHC and ICF KH had also performed sampling and analysis at some locations in the 3000 Area prior to USACE's work on the Operable Unit 1100-EM-3. They removed a number of USTS and performed remediation.

The following is a discussion of WMUs from category 1 , work performed by WHC and ICF KH, and other locations of potential environmental concerns identified during this assessment.

\section{WMUs from USACE Category 1}

\section{1208 Hazardous Waste staging area (HWSA)}

This HWSA (90-day Accumulation Area) was located on the east side of Building 1208. All the waste from the paint shop was stored in containers on a concrete pad. Weekly inspections were performed. Typical wastes, contained in staging, include paints and solvents, $\approx 1,136$ liters $/ \mathrm{yr}$ ( $300 \mathrm{ga} 7)$. The paint shop has moved out of the building. No environmental problems associated with this operation were observed.

\section{1226 HWSA}

This HWSA is a Satellite Accumulation Area (Photograph 3). Typical wastes contained in storage include oils, solvents, antifreeze, and degreasers in 208 liters (55 gallon) drums, $\approx 1,136$ i iters $/ \mathrm{yr}$ (300 gal/yr). Week7y inspections are performed. No environmental problems have been reported.

\section{1240 HWSA}

This HWSA was located at the Building 1240 Machine Shop. Building is now vacant and the HWSA is gone. There were no obvious signs of any spills at this location.

\section{1234 Simulated High-Level Waste Slurry Treatment \& Storage Yard}

Pacific Northwest Laboratory (PNL) has prepared a closure plan (DOE/RL 88-08) for this location. This cleanup was completed and a closure certificate was sent to DOE/RL for signature on August 10, 1995. No further monitoring is required at this location (Photograph 4 ) 
WHC-SP-1167

Rev. 0

\section{Twelve UST Removal/Closure Sites (Figure 5)}

See section on USTS removed by WHC and ICF KH.

\section{1235 Bottle Dock}

Currently used by ICF KH as a 90-Day Accumulation Area (Photograph 5). No environmental problems were reported.

\section{1240 Compressor 0il Spill Area}

USACE state in report DOE/RL-92-67 that an area of old spill was observed and it was cleaned up. The report further states that records indicated the spill was cleaned up to less than $2 \mathrm{ppm}$ PCB's in soil.

\section{JA Jones Yard HWSA}

This HWSA was located south of Building 1226 in the southeast corner of the fenced area. Hanford Waste Management Units Report, DOE/RL-88-30, volume 2 of 2 states that in October 1986, it was discovered that many of the containers in storage had failed, and an area of the storage yard $\approx 0.5$ to 1 meters $(\approx 1$ to 2 feet) deep over 84 square meters (900 square feet) was found to be contaminated with up to $978 \mathrm{ppm}$ lead.

A11 leaking drums were over-packed and sampled to determine the origin of the lead in the soil. The drums contained approximately 50 cubic meters $(1,800 \mathrm{cu}$ feet) of soil from the location (down to background concentrations of lead; 21 $\mathrm{ppm}$ ) and were drummed for disposal off-site as hazardous waste.

A maximum of two hundred 208 liters ( 55 gallon) drums of nonregulated oils were stored at this location, along with fourteen 55-gal drums of antifreeze and paint-reacted materials.

\section{Unplanned Release of Mixed Waste}

A technician disposed of $2.0 \mathrm{E}-06 \mathrm{Ci}$ of $\mathrm{Cs}-134$ in $1,650 \mathrm{~m} 7$. solution in the sink. Solution was discharged accidently into the Richland city sewer system in 1973. The sink, trap and drain were surveyed after the discharge; no radioactivity was found. This incident occurred in 1973 in laboratory 1623 in the PS building. The building is no longer around and this incident should not be a problem.

10. Dirt Mound in the southwest corner of the 3000 Area

The dirt came from UST excavation at Building 1207 (Photograph 6). This was done about 5 years ago. Some loose equipment is scattered around and within the mound. 
WHC-SP-1167

Rev. 0

11. 1212 Bottle Dock.

The building was demolished and the area has been graveled. No environmental problems were noted.

12. 3000-12 UST (Figure 5))

See section on USTs removed by WHC and ICF KH. 
WHC-SP-1167

Rev. 0

\section{USTS REMOVED BY WHC AND ICF KH}

UST 3000-1: A 56,775 1iters (15,000 gallons), single walled, steel tank containing unleaded fuel was removed on January 18, 1991. Samples were taken following removal and contamination above acceptable limits was found. The site was remediated by removal of the contaminated soil and backfilled with clean fill.

UST 3000-2: A 56,775 liters (15,000 gallon), single walled, steel tank containing diesel (used for unleaded fuel in past) was removed on January 18 , 1991. Samples were taken following removal and contamination above acceptable limits was found. The site was remediated by removal of the contaminated soil and backfilled with clean fill.

UST 3000-3: A 56,775 liters (15,000 gallon), single walled, steel tank containing regular fuel was removed on January 16, 1991. Samples were taken following removal and contamination above acceptable limits was found. The site was remediated by removal of the contaminated soil and backfilled with clean fill.

UST 3000-4: A 56,775 liters (15,000 gallon), single walled, steel tank containing regular fuel was removed on January 16, 1991. Samples were taken following removal and contamination above acceptable limits was found. The site was remediated by removal of the contaminated soil and backfilled with clean fill.

UST 3000-5: A 75,700 liters (20,000 gallons), single walled, steel tank containing diesel fuel was removed on September 15, 1989. Samples were taken following removal and contamination above acceptable limits was found. The site was remediated by removal of the contaminated soil and backfilled with clean fill.

UST 3000-6: A 75,700 liters (20,000 gallons), single walled, steel tank containing diesel fuel was removed on September 15, 1989. Samples were taken following removal and contamination above acceptable 1 imits was found. The site was remediated by removal of the contaminated soil and backfilled with clean fill.

UST 3000-7: A 37,850 liters (10,000 gallons), single walled, steel tank last containing Sodium Lignosulfonate and it was removed in October 1989 . No contamination was found and the site was backfilled with a clean fill.

UST 3000-8: A 47,313 liters (12,500 gallons), single walled, steel tank containing leaded gasoline was removed in October, 1989. Samples were taken following removal and no contamination above acceptable limits was found. The site was backfilled with clean fill. 
UST 3000-9: A 47,313 liters (12,500 gallons), single walled, steel tank containing leaded gasoline was removed in 0ctober, 1989. Samples were taken following removal and no contamination above acceptable limits was found. The site was backfilled with clean fill.

UST 3000-10: A 47,313 liters (12,500 gallons), single walled, steel tank containing leaded gasoline was removed in October, 1989. Samples were taken following removal and no contamination above acceptable limits was found. The site was backfilled with clean fill.

UST 3000-11: A 47,313 liters (12,500 gallons), single walled, steel tank containing diesel fuel was removed in October, 1989. Samples were taken following removal and no contamination above acceptable limits was found. The site was backfilled with clean fill.

UST 3000-12: A less than 3,785 liters (1,000 gallons), single walled, steel tank containing used/waste oil was removed on April 2, 1993. Samples were taken following removal and contamination above acceptable limits was found. The site was remediated by removal of the contaminated soil and backfilled with clean fill.

UST 3000-13: A 47,313 liters (12,500 gallons), single walled, steel tank last containing diesel fuel was removed in October, 1989. Samples were taken following removal and no contamination above acceptable limits was found. The site was backfilled with clean fill. 
WHC-SP-1167

Rev. 0

\section{ENVIRONMENTAL CONDITIONS IDENTIFIED DURING THE ASSESSMENT}

The entire 3000 area was walked down to identify potential environmental problems. Some oil stains were noted in the area between 1262 and 1264 on the east of the buildings. This area is used as a parking area. Spots of red garnet sand were observed NE of Building 1264, and in the vicinity of the dumpster near Building 1262.

Several small piles of soil, on the order of 5-10 cu yards, were observed in the area NE of Building 1208. Some piles had debris, i.e. railroad tie, intermixed with the soil (Photograph 7).

Several piles of railroad ties, rusty equipment parts, and soil were observed along the southern boundary of the property (Photograph 8). North of Building 1154 there is a U.S. West laydown yard strewn with cable spools, cable and other related items. Just NW of the laydown yard are a number of empty 208 liters (55 gallon) drums.

There are seven groundwater monitoring wells in the 3000 Area. They are used to study groundwater characteristics. Some of them were drilled by USACE during the remediation work conducted at the operable unit 1100-EM-3. Pacific Northwest Laboratory is the custodian of four wells, while USACE is the custodian for the remaining three wells.

There are four pieces of construction equipment, i.e., mobife compressors being stored near the south boundary a little southwest of Building 1226 . They are in a roped off Radioactive Contamination Zone and are labeled appropriately. They are to be moved from the 3000 Areas.

ACM were reported to be present in the form of caulking material, insulation, siding and vinyl floor tiles in Buildings 1154, 1209, 1240, 1241, 1242, 1252, 1256, 1262 (Photographs 9-13).

Following is a discussion of potential environmental problems associated with buildings in the 3000 area.

\section{Building 1154}

This building has pipes covered with Asbestos Containing Material (ACM) in a pipe chase tunnel on the north side of the building and inside the building.

\section{Building 1208 and the Sandblast Area}

Building 1208 is vacant. The residue of the blasted material outside the building was sampled by ICF KH and found to be regulated (Photograph 14 ). 
WHC-SP-1167

Rev. 0

\section{Building 1240}

On the north side of the building is an approximately 1.2 meters $\times 3$ meters ( 4 feet $\times 10$ feet) pit with what appears to be a sump grate in the northeast corner. There used to be a Wallace 6" pipe bender machine at this location (Photograph 15). The machine was recently removed from the pit.

\section{Building 1241}

There is a trench containing hydraulic oil where a plate shear machine was located. It may be mixed with some gear oil.

\section{Service Station}

No information available.

\section{Building 1226}

The following problems were identified at Building 1226:

- A hydraulic hoist was removed from the north end of the building but the cylinders were reportedly left behind. Condition of the cylinders is unknown and they may be leaking hydraulic oil. Currently they are covered with concrete (Photograph 16).

- Two 18" square patches of concrete are located just south of the above noted hoist area. Tapping on them results in a hollow sounding noise. Believed to be location of original vehicle hoists.

- There is an add-on compressor room attached to the building on the east side. Significant oil staining of the concrete floor (Photograph 17). Also oil stains were noted on the exterior walls of the compressor room (Photograph 18).

- There is a small drip of oil under the compressor motor in the sprinkler system control room.

- There is a dry well located on the south end of the building to handle steam condensate. The operation has been discontinued. No environmental problem is associated with this.

- There is a Satellite Accumulation Area on tho west side. No environmental problem was observed at this location.

- There is an $011 /$ water separator on the west side as part of the steam cleaning operations. No environmental problem was observed at this location. 
0. Part of the building has cement asbestos board siding which contains asbestos. Numerous siding panels were chipped and broken (Photograph 19).

\section{Building 1242}

Building 1242 houses a compressor which holds 26 liters ( 7 gallons) of oil. The area around the compressor is heavily stained as is the area outside on the west side of the building (Photograph 20). There is an above-ground tank located on the east side of the building (Photograph 21). It was installed about eight years ago and was used to catch exhaust air from the compressor. The air was contaminated with 0 il/water. The contents of the tank were emptied into 55 gallon drums.

\section{Laydown Yard West of Building 1253}

This yard is currently vacant. It is sometimes used by ICF KH to store equipment.

\section{RECOMMENDATIONS}

All the ACM in the buildings in the area should be identified and friable ACM should either be removed or encapsulated. For nonfriable ACM, proper warning signs should be posted as required.

\section{Building 1208 And The Sandblast Area}

The floor drains need further investigation to determine their direction and length and whether or not they are connected to the sanitary sewer. The soil at the discharge point will have to be characterized if necessary.

\section{Service Station}

A GPR survey should be conducted to verify presence or absence of an UST.

\section{Building 1226}

- Determine if the two hydraulic rams, covered with concrete, are leaking.

- Investigate two 18" square patches of concrete that are located just south of the above noted hoist area.

- Characterize oil stains outside the building including the compressor room and remediate the stained areas if necessary. 
WHC-SP-1167

Rev. 0

\section{Building 1241}

The hydraulic oil in the trench where a plate shear machine was located should be characterized and removed.

\section{Building 1242}

Clean the heavily stained area around the compressor. The stained area outside the building should be characterized and remediated, if necessary.

\section{J. A. Jones $0 i 1$ Storage Tanks}

The ancillary piping should be removed (Photograph 22). 
WHC-SP-1167

Rev. 0

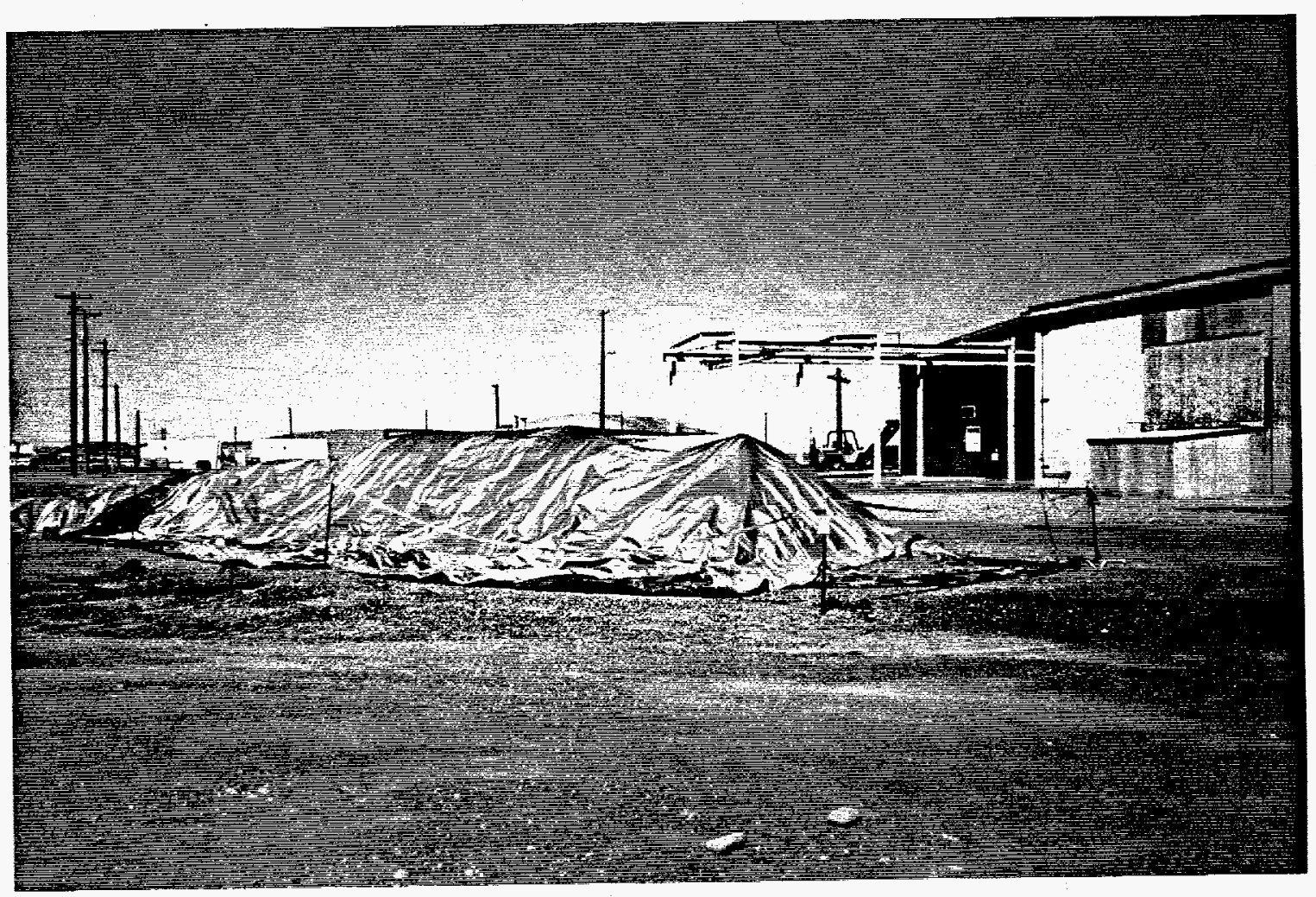

Photograph 1: Soil removed from Building 1240 Suspect $0 i 1$ Spil1 area. 
WHC-SP-1167

Rev. 0

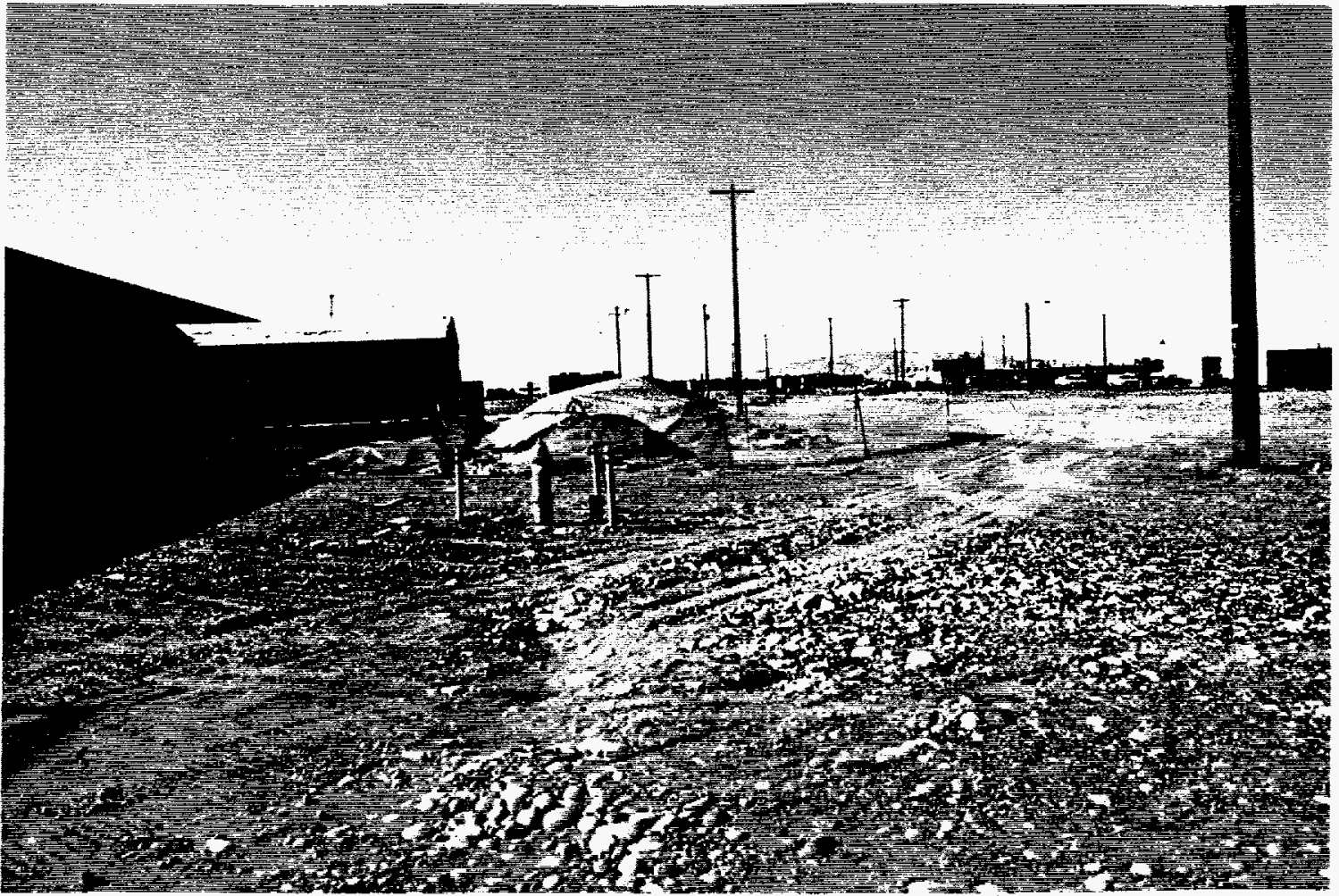

Photograph 2: Soil removed from Building 1240 French Drain. 
WHC-SP-1167

Rev. 0

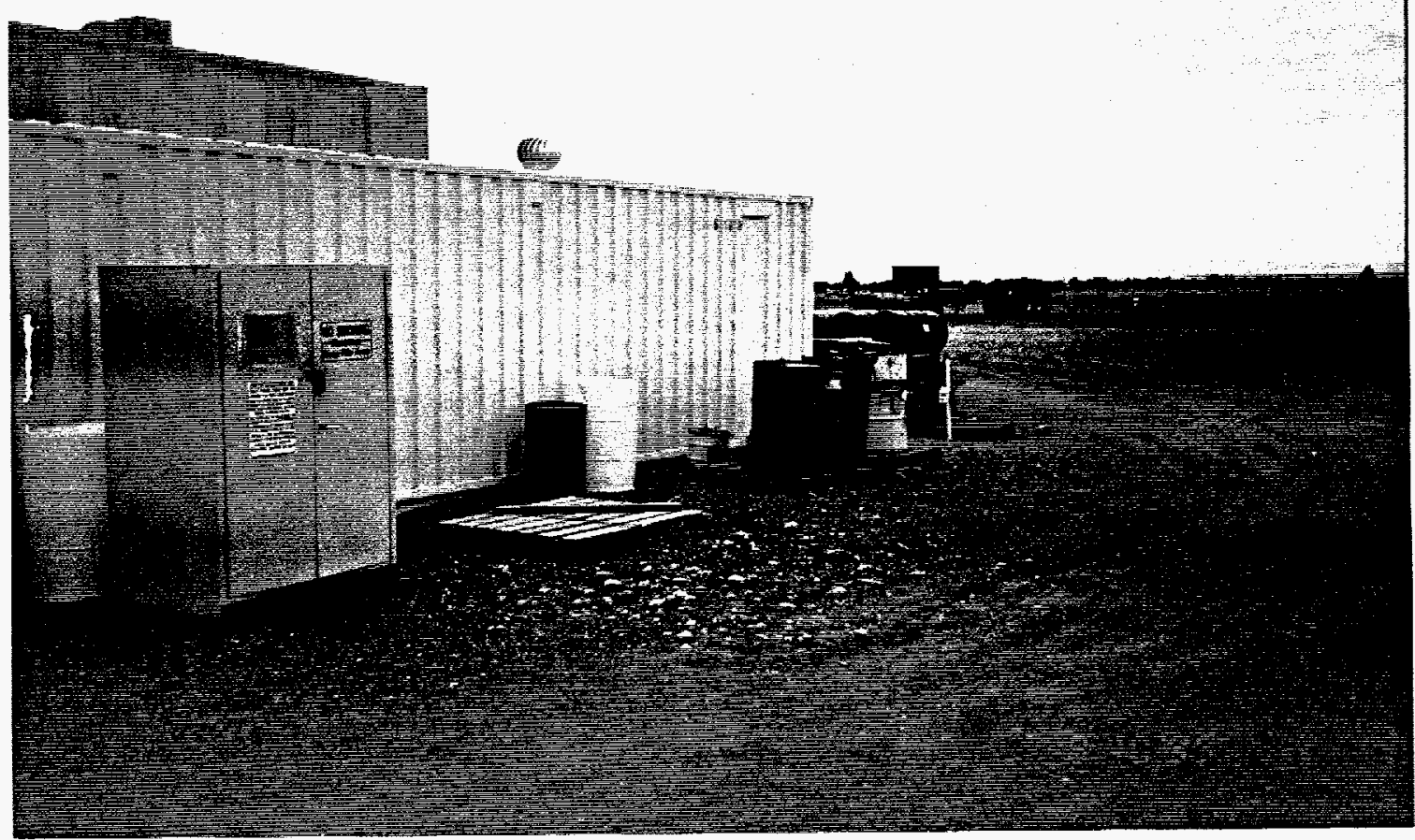

Photograph 3: Satellite Accumulation Area at Building 1226. 
WHC-SP-1167

Rev. 0

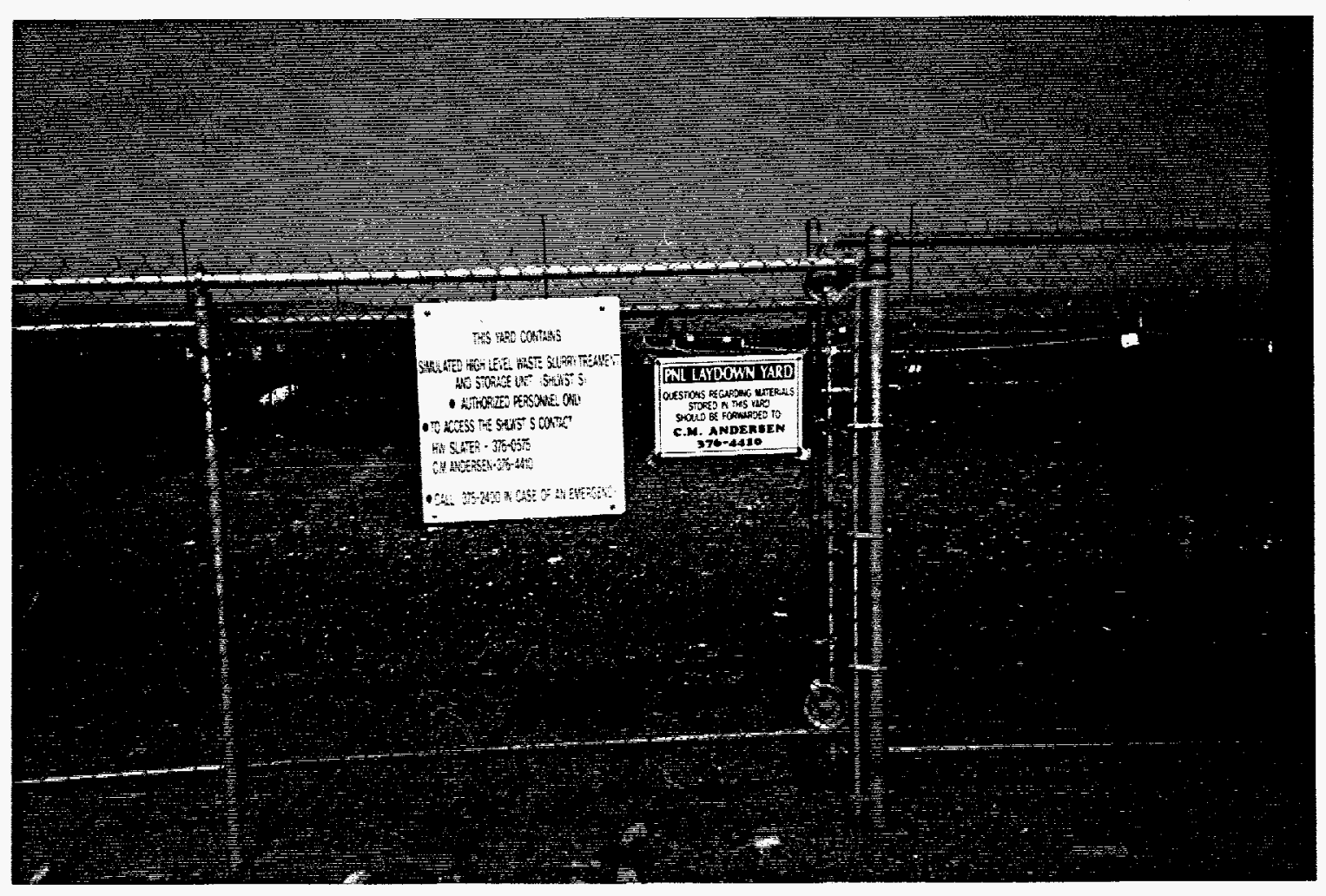

Photograph 4: 1234 Simulated High-Level Waste Slurry Treatment \& Storage Yard. 
WHC-SP-1167

Rev. 0

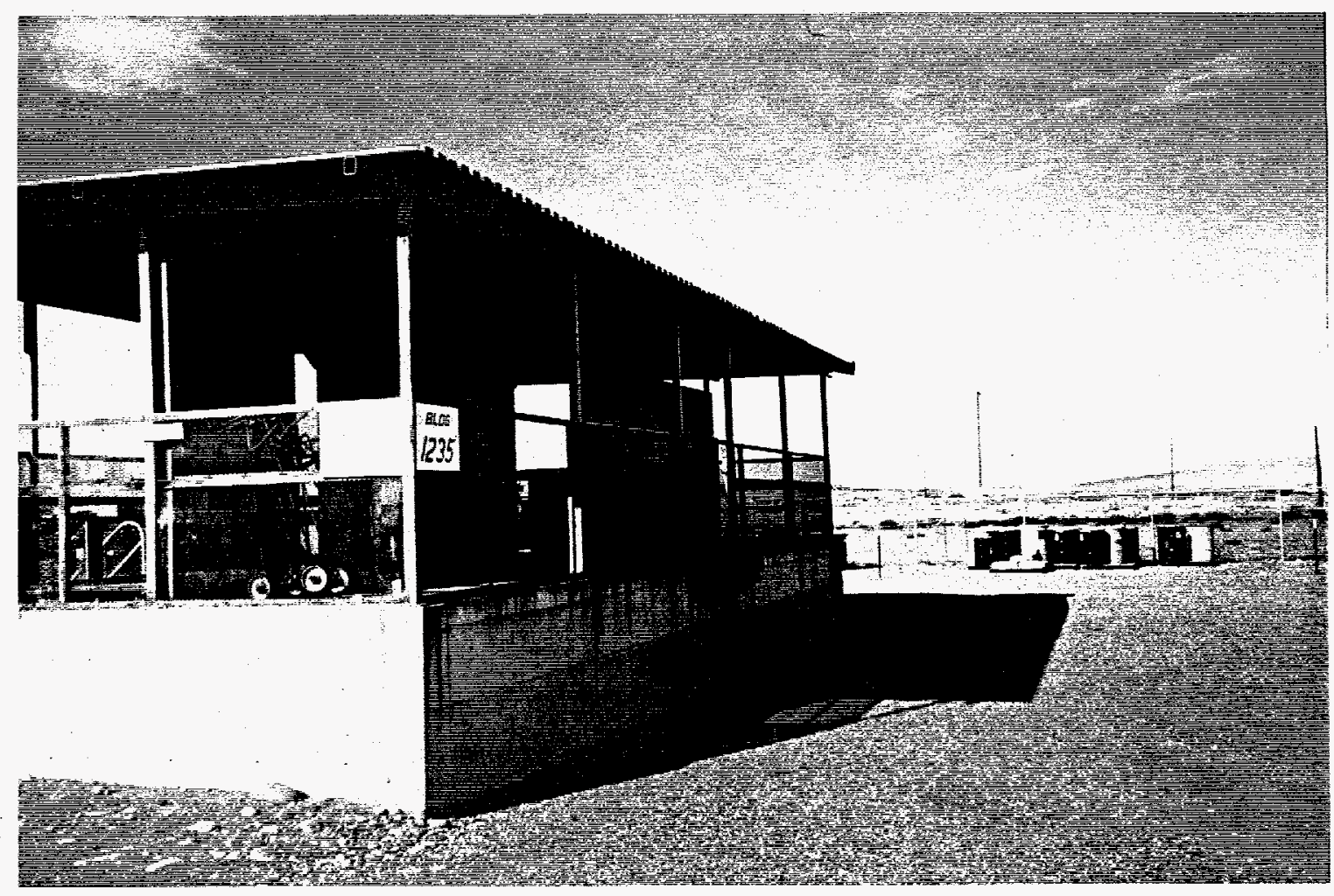

Photograph 5: 1235 Bottle Dock. 
WHC-SP-1167

Rev. 0

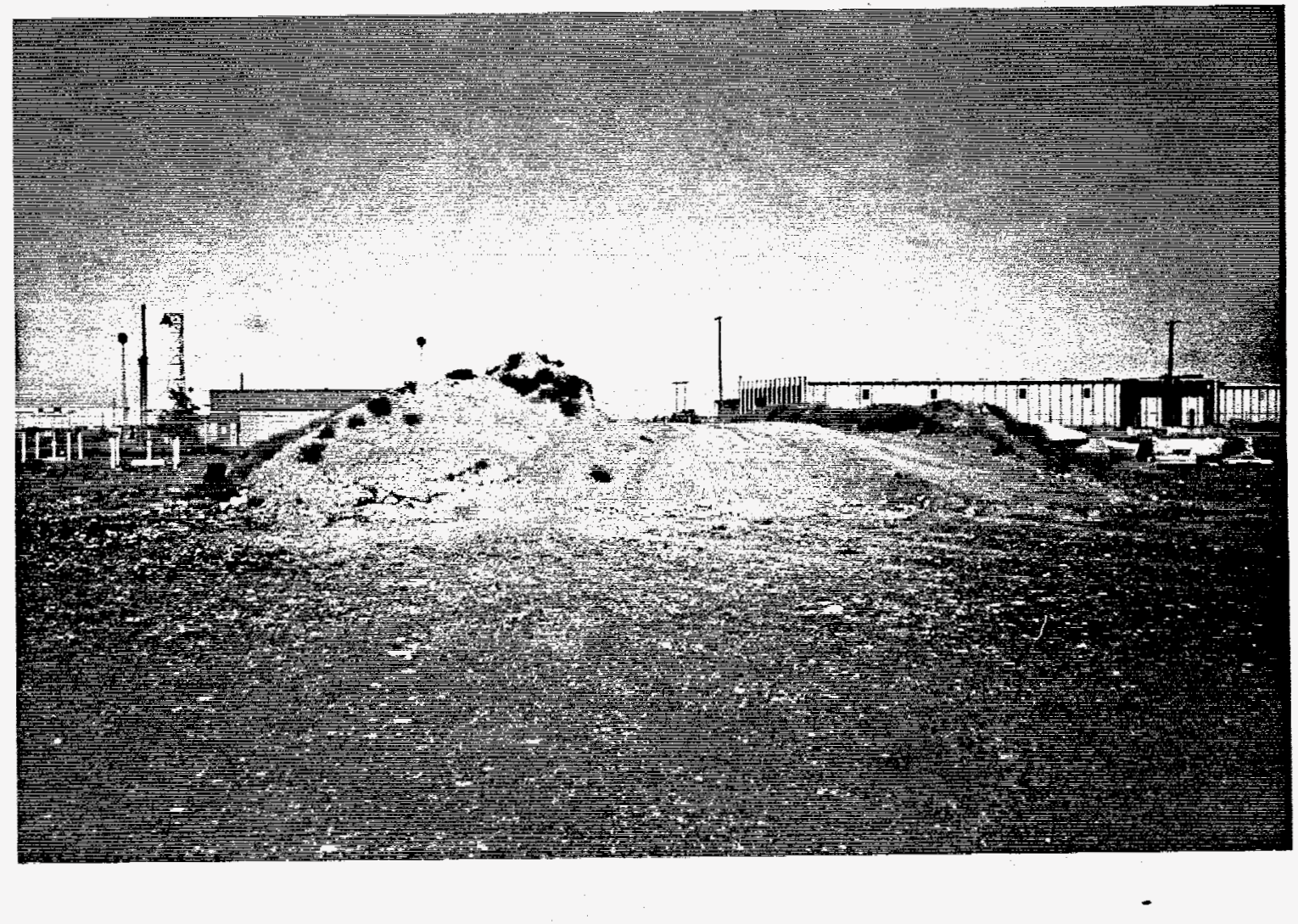

Photograph 6: Dirt Mound in the southwest corner of the 3000 Area 
WHC-SP-1167

Rev. 0

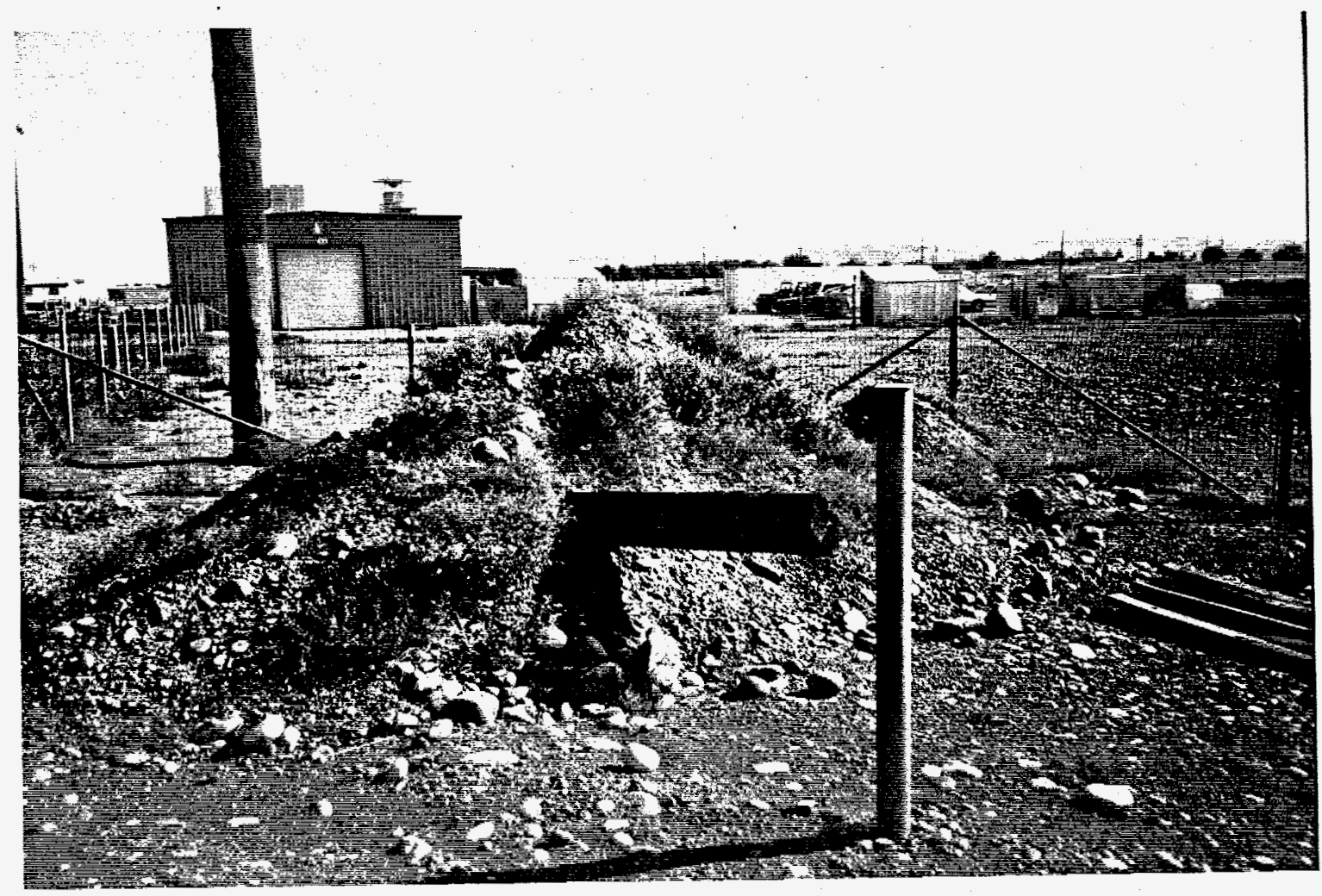

Photograph 7: Soil pile on the northeast of Building 1208. 
WHC-SP-1167

Rev. 0

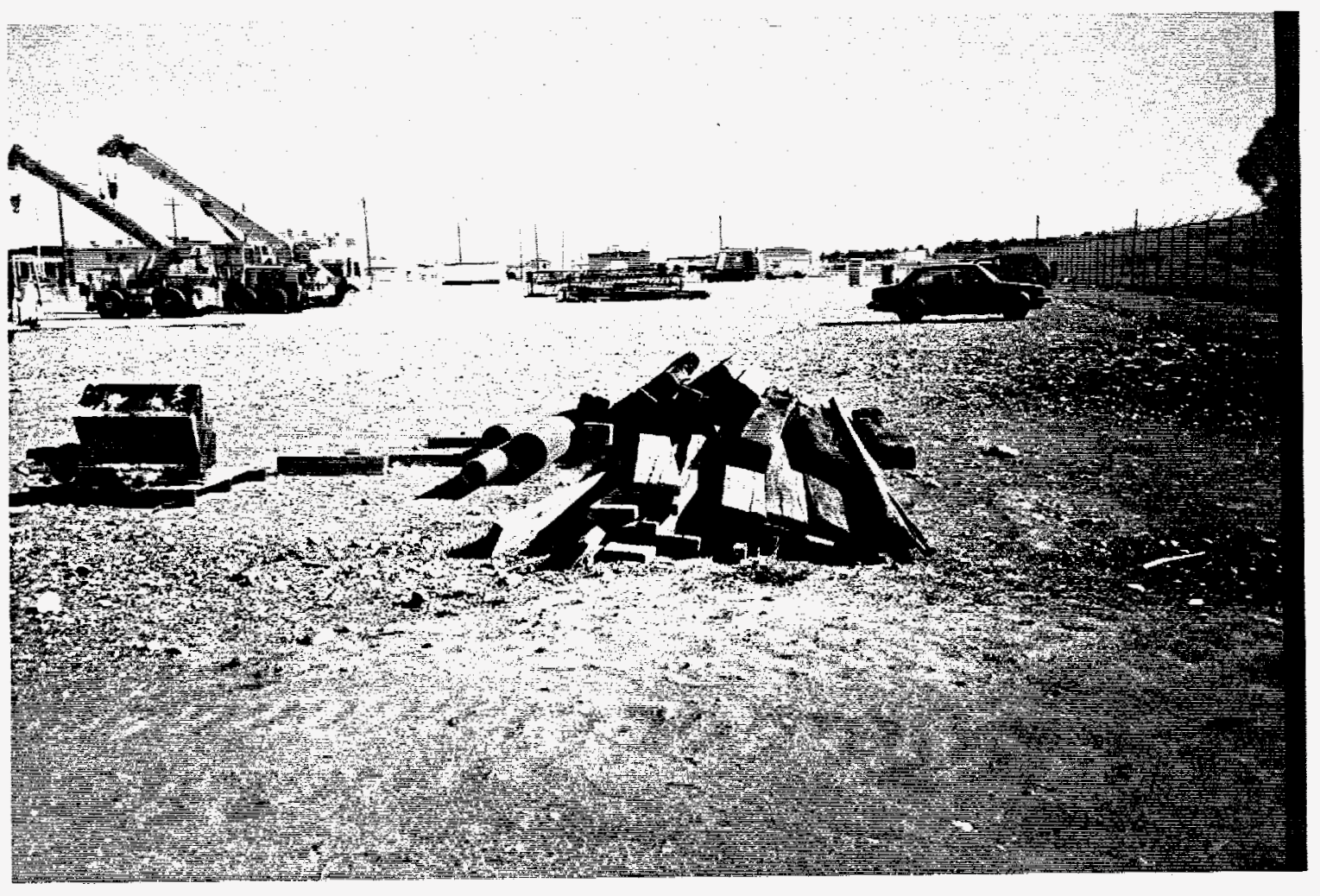

Photograph 8: Railroad ties in the southeast part of the 3000 Area. 
WHC-SP-1167

Rev. 0

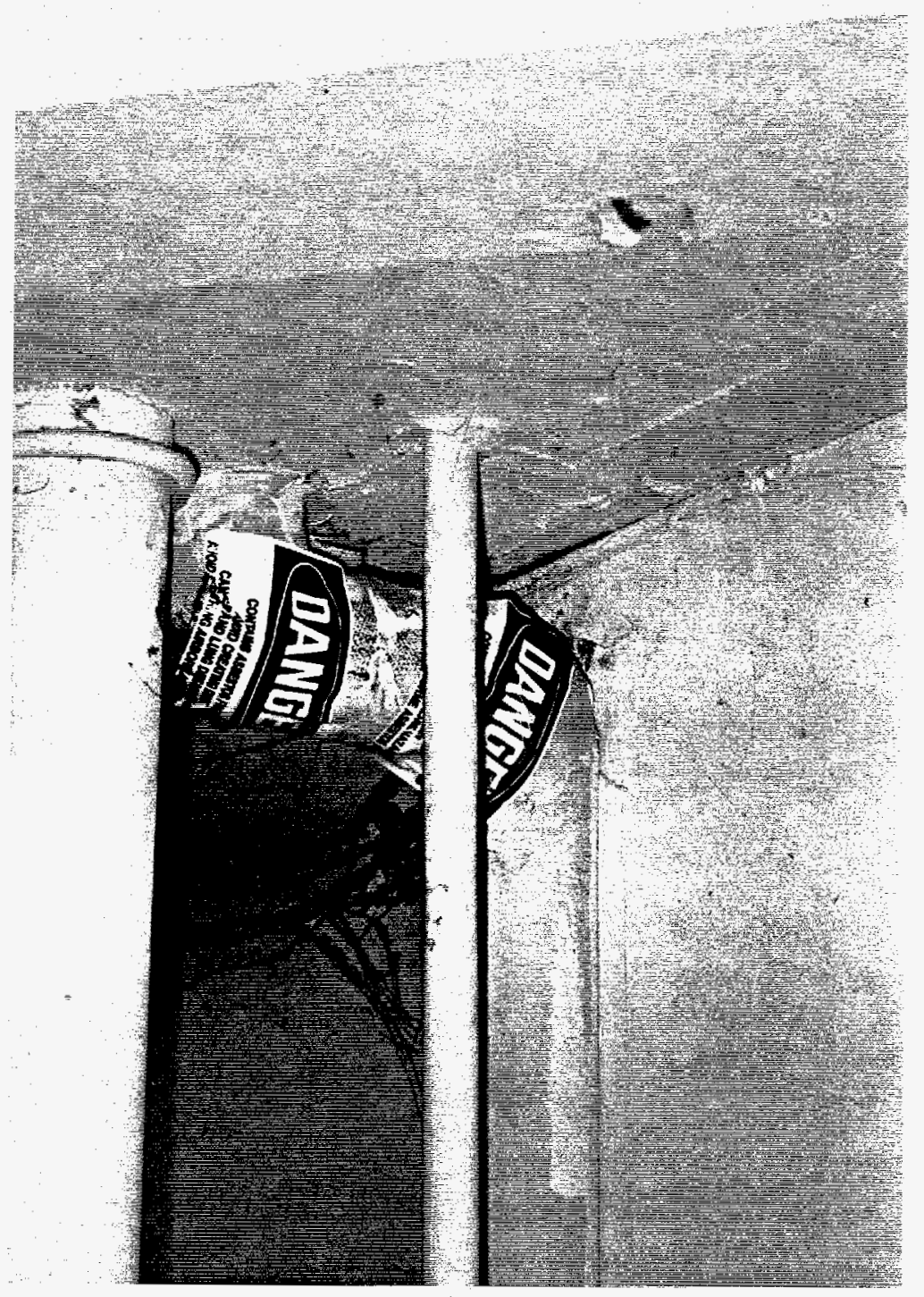

Photograph 9: Damaged ACM on kitchen area pipe elbow in Building 1256 
WHC-SP-1167

Rev. 0

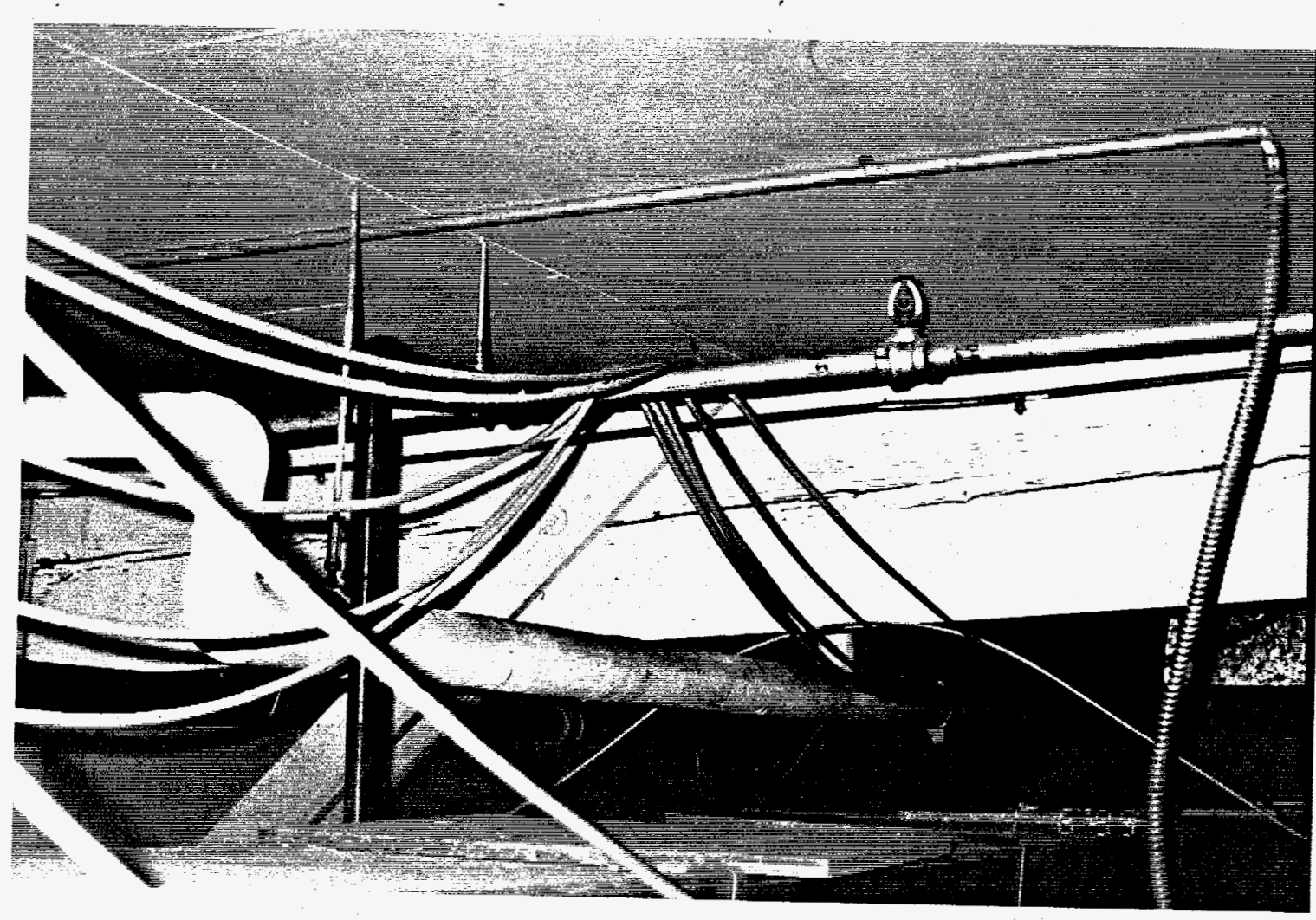

Photograph 10: Thermal pipe insulation in poor condition above the ceiling in crawl space in Building 1256 
WHC-SP-1167

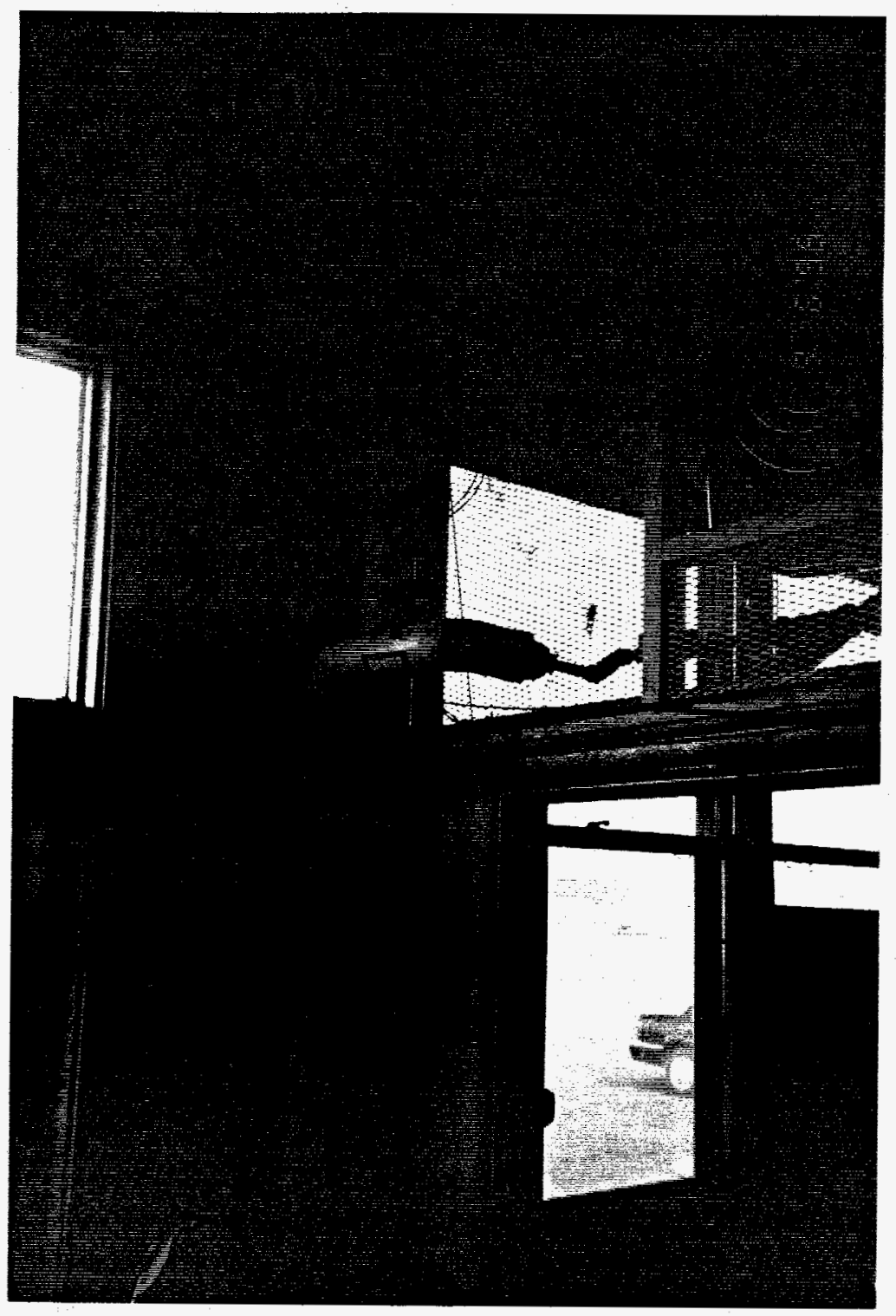

Rev. 0

Photograph 11: Thermal pipe insulation in fair condition, just inside the entry in Building 1154 
WHC-SP-1167

Rev. 0

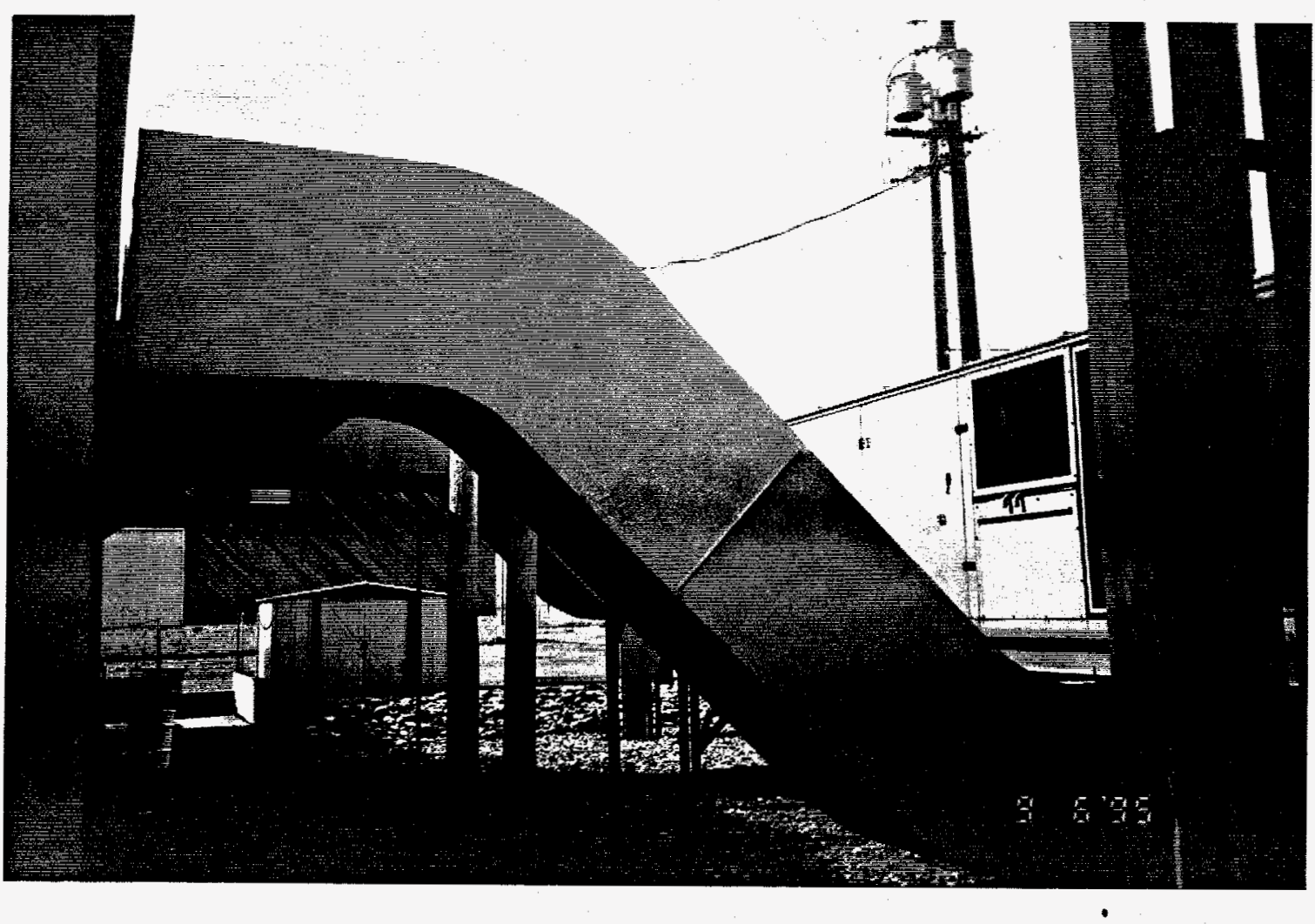

Photograph 12: Duct work with insulation in good condition, outside north end of Building 1256 
St to IE

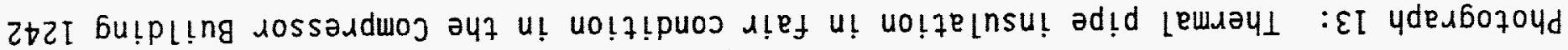




WHC-SP-1167

Rev. 0

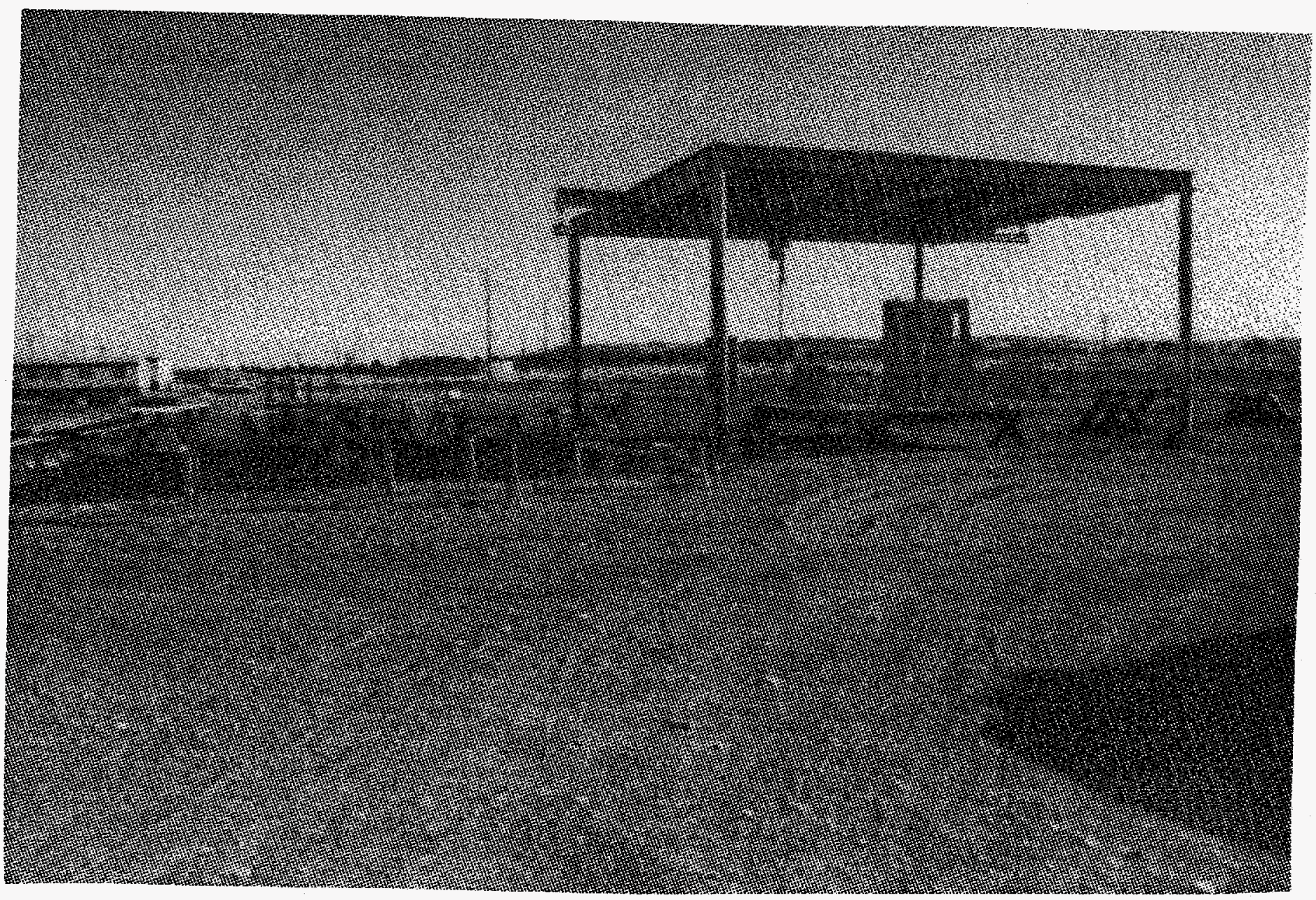

Photograph 14: 1208 Sandblast Area 
WHC-SP-1167

Rev. 0

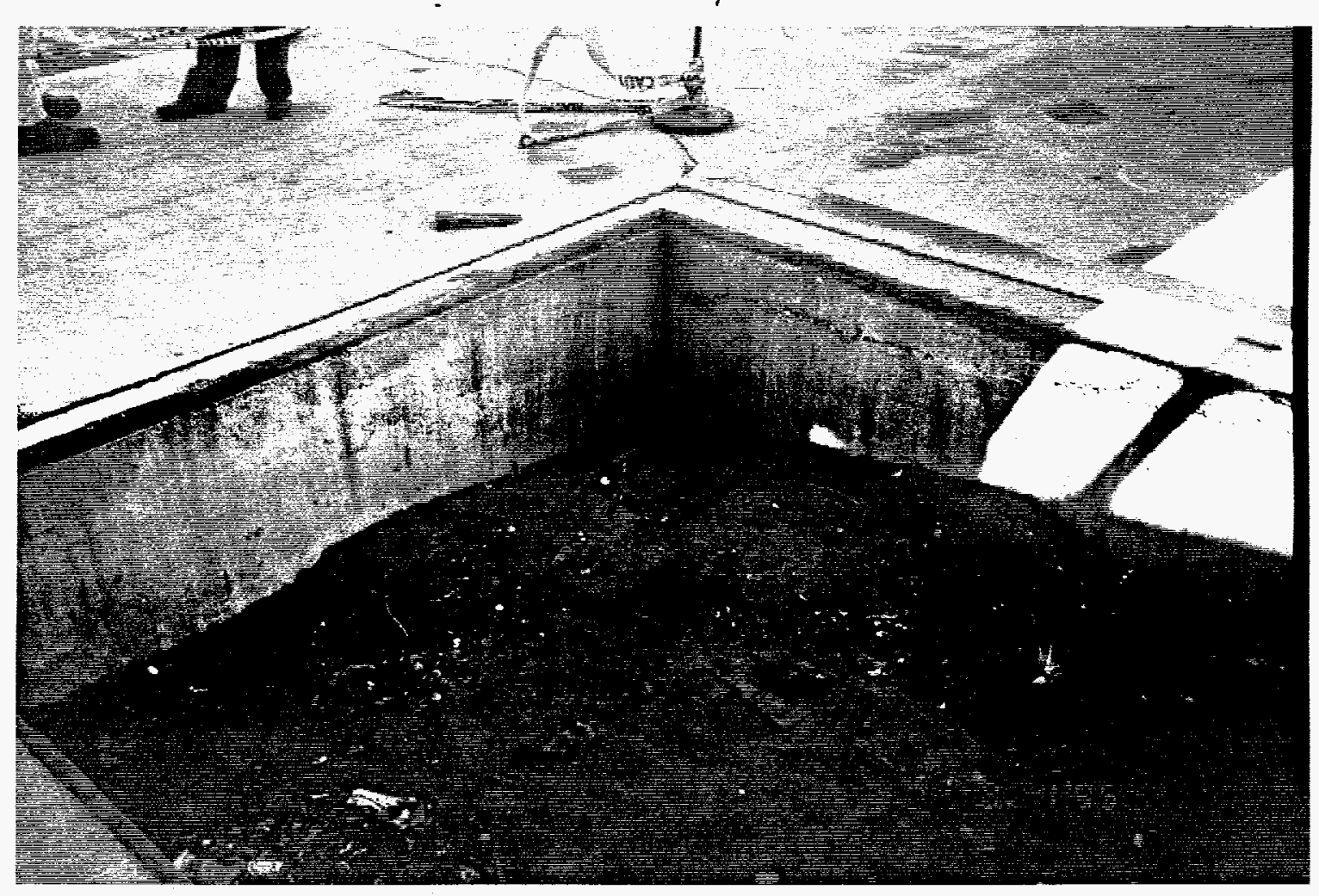

Photograph 15: Machine pit filled with oil stained soil. Drain grate outline is visible in the center of the picture 
WHC-SP-1167

Rev. 0

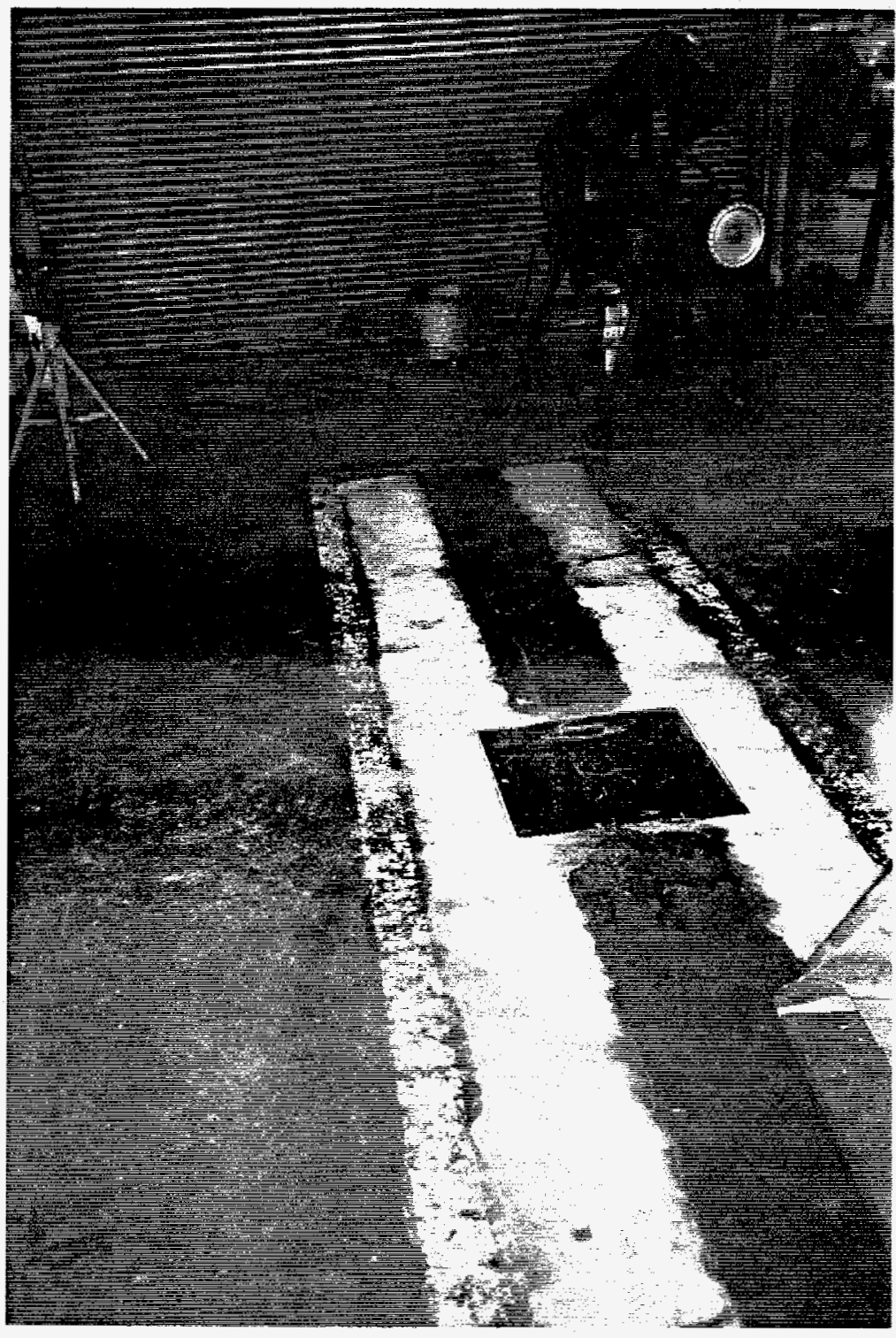

Photograph 16: Location of former vehicle hydraulic hoist, Building 1226 
WHC-SP-1167

Rev. 0

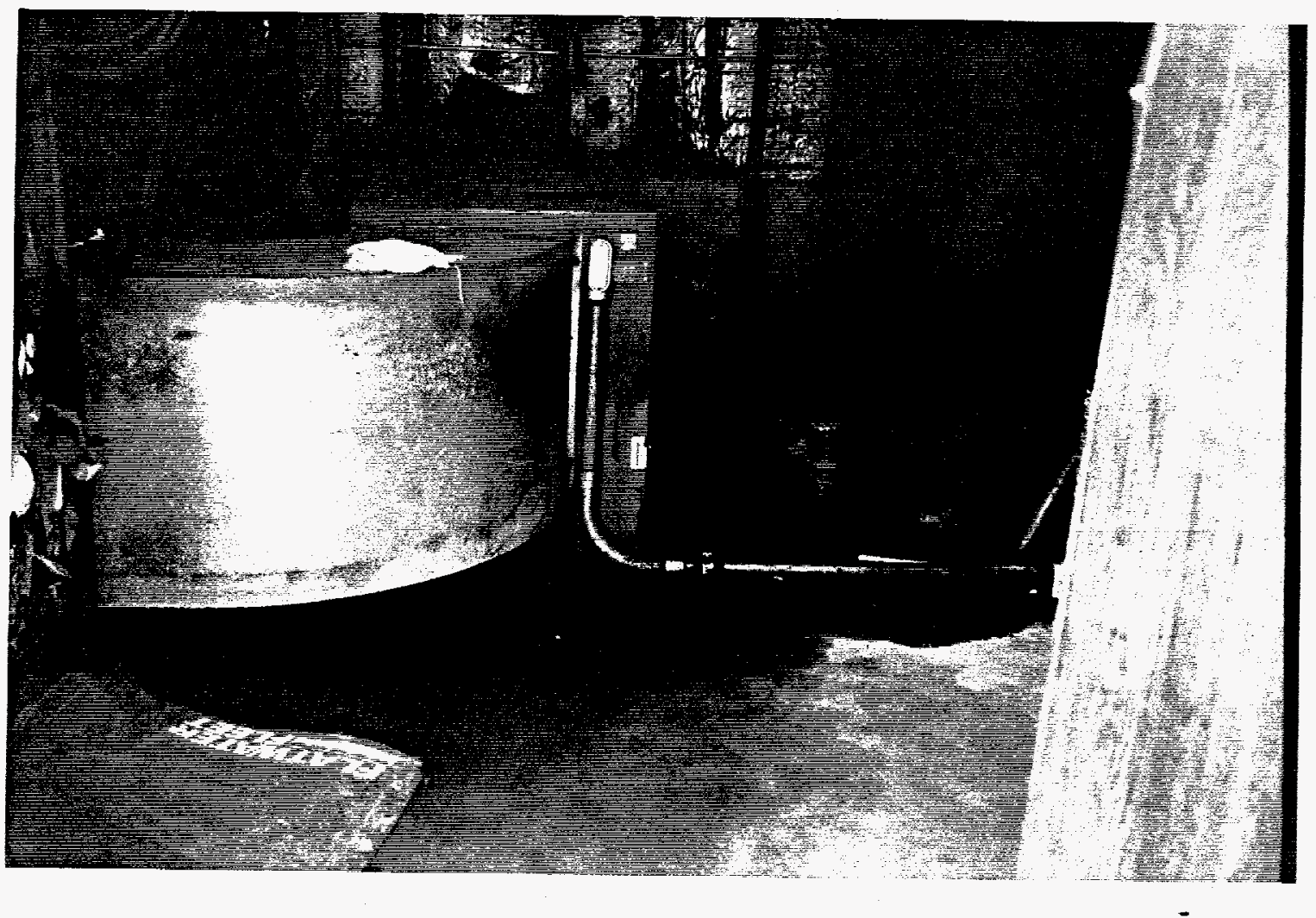

Photograph 17: $0 i 1$ stained concrete floor in the compressor room, Building 1226 
WHC-SP-1167

Rev. 0

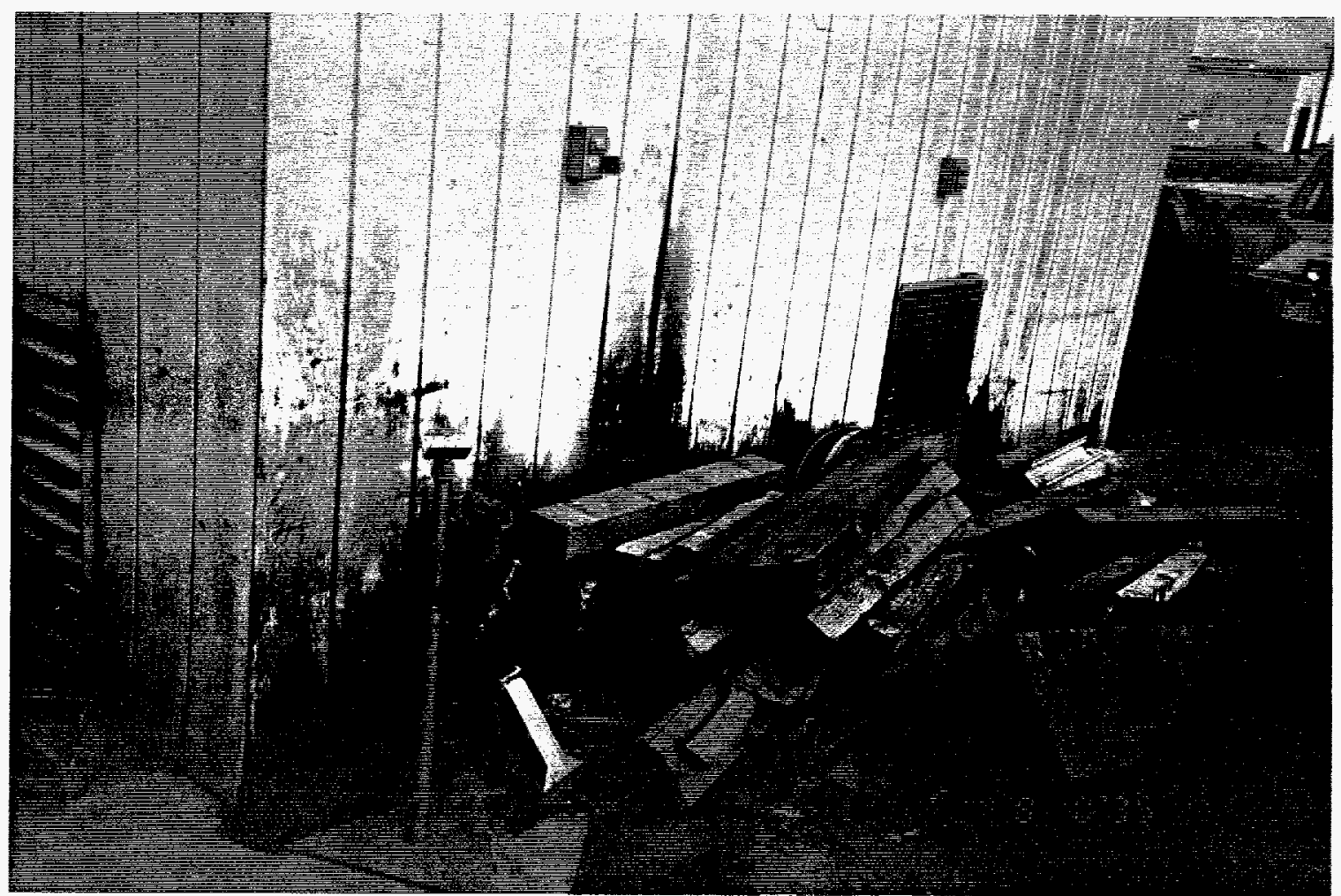

Photograph 18: 0il leaking through siding of compressor room, Building 1226 
st to $L \varepsilon$

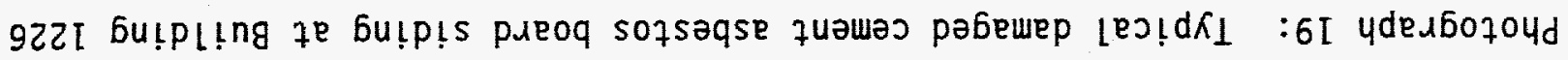

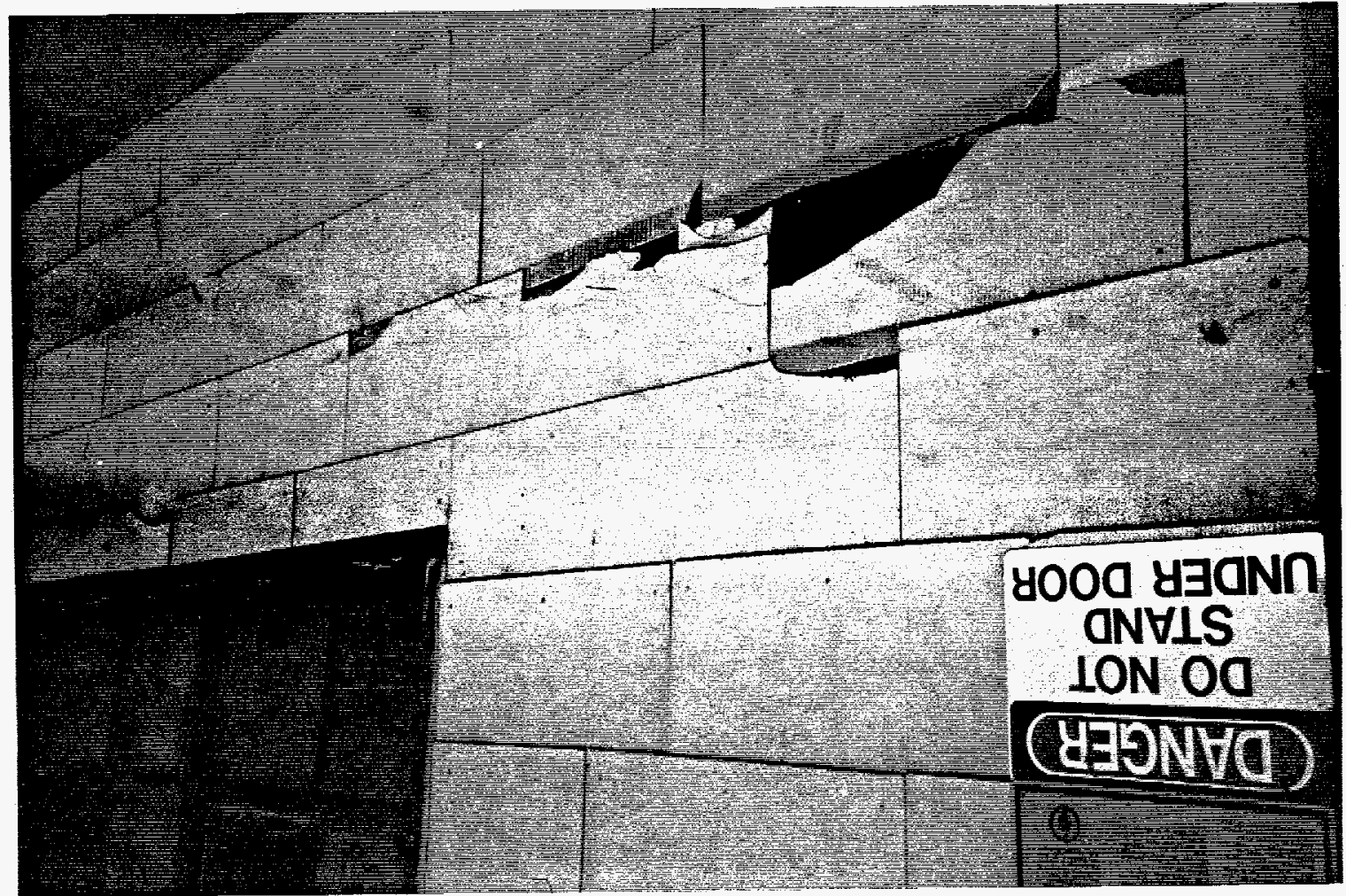

0 - ^ау

L9II-dS-JHM 
WHC-SP-1167

Rev. 0

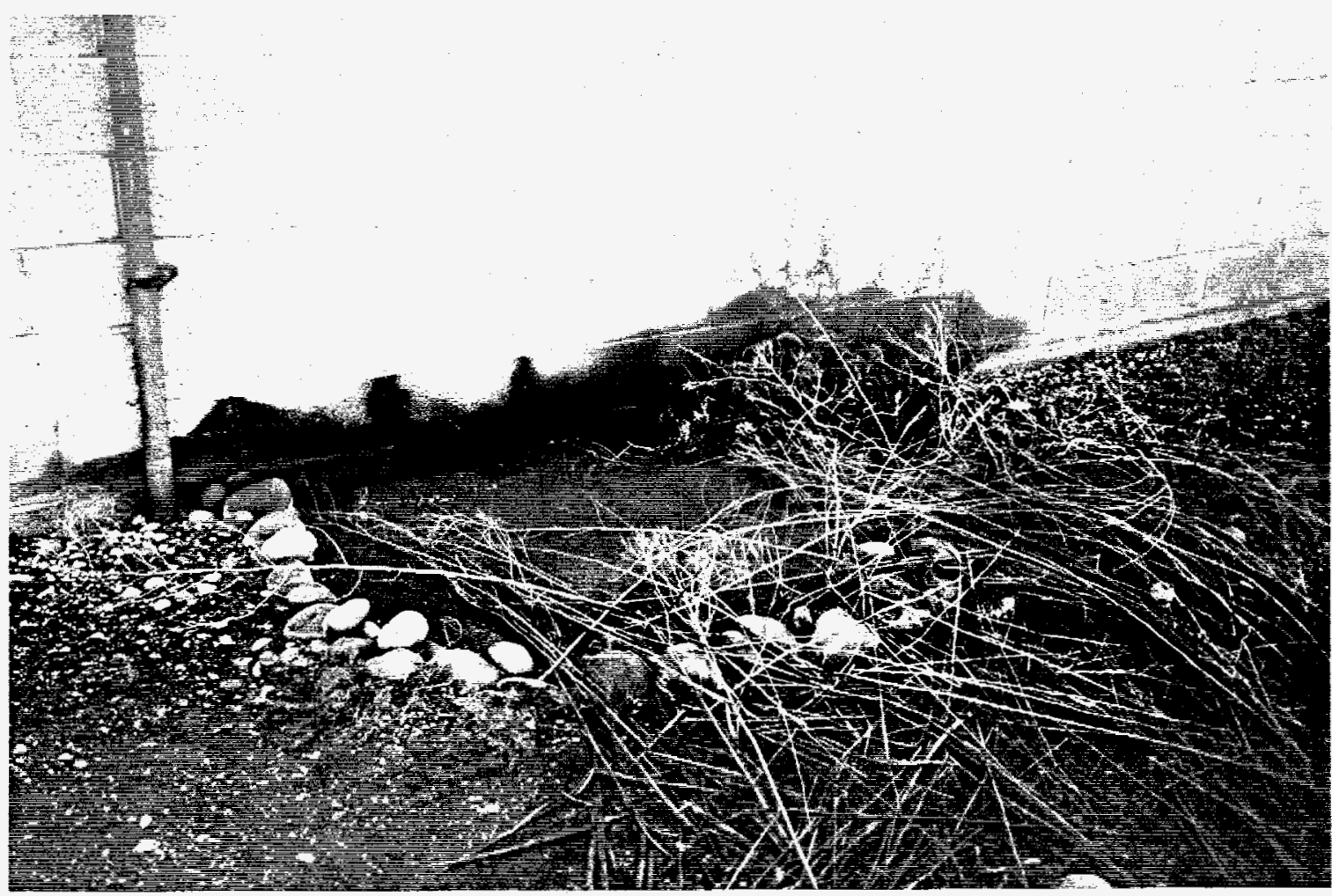

Photograph 20: $0 i 1$ stained ground outside the west side of Building 1242 . 
WHC-SP-1167

Rev. 0

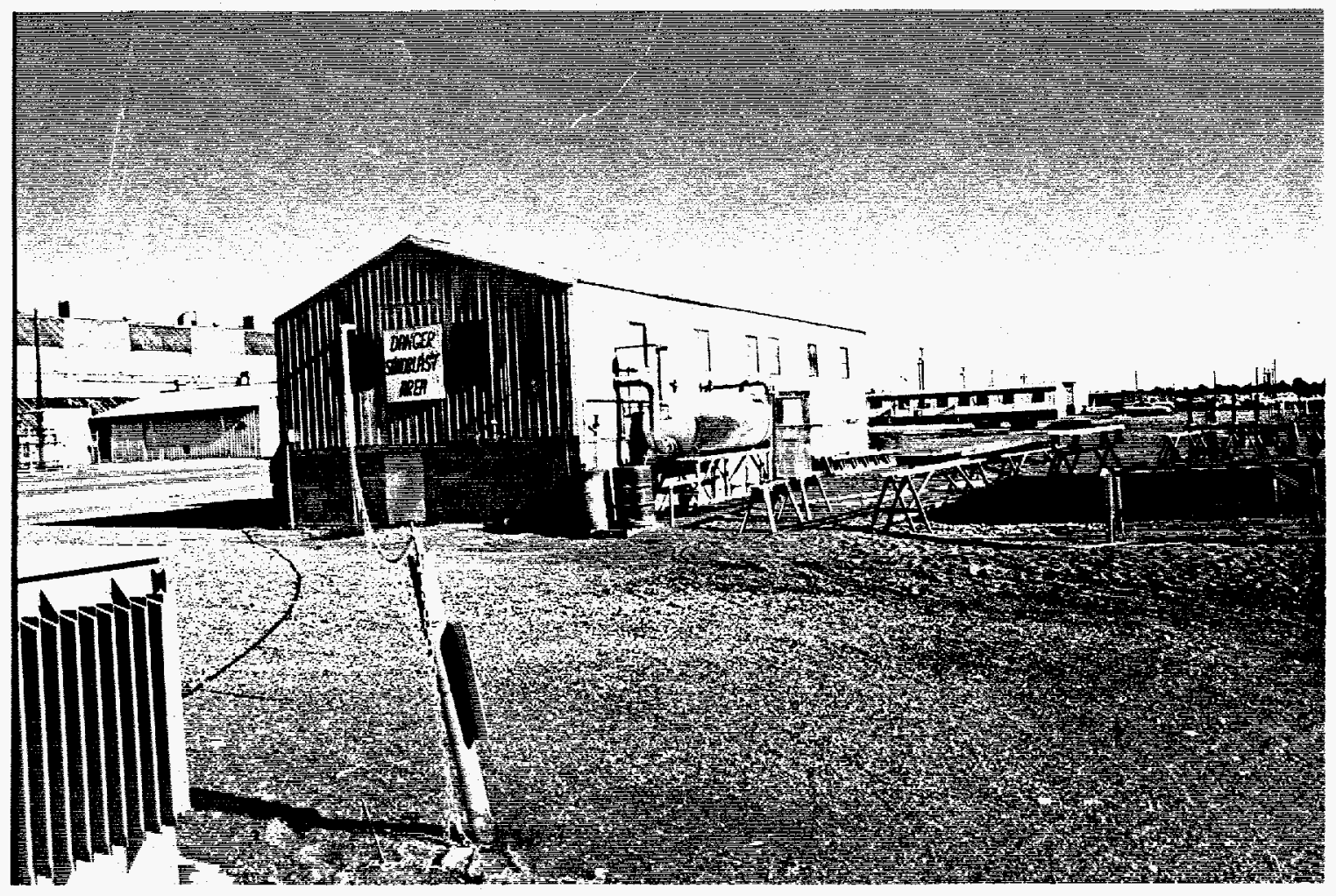

Photograph 21: Above-ground tank on the east side of Building 1242 . 
WHC-SP-1167

Rev. 0

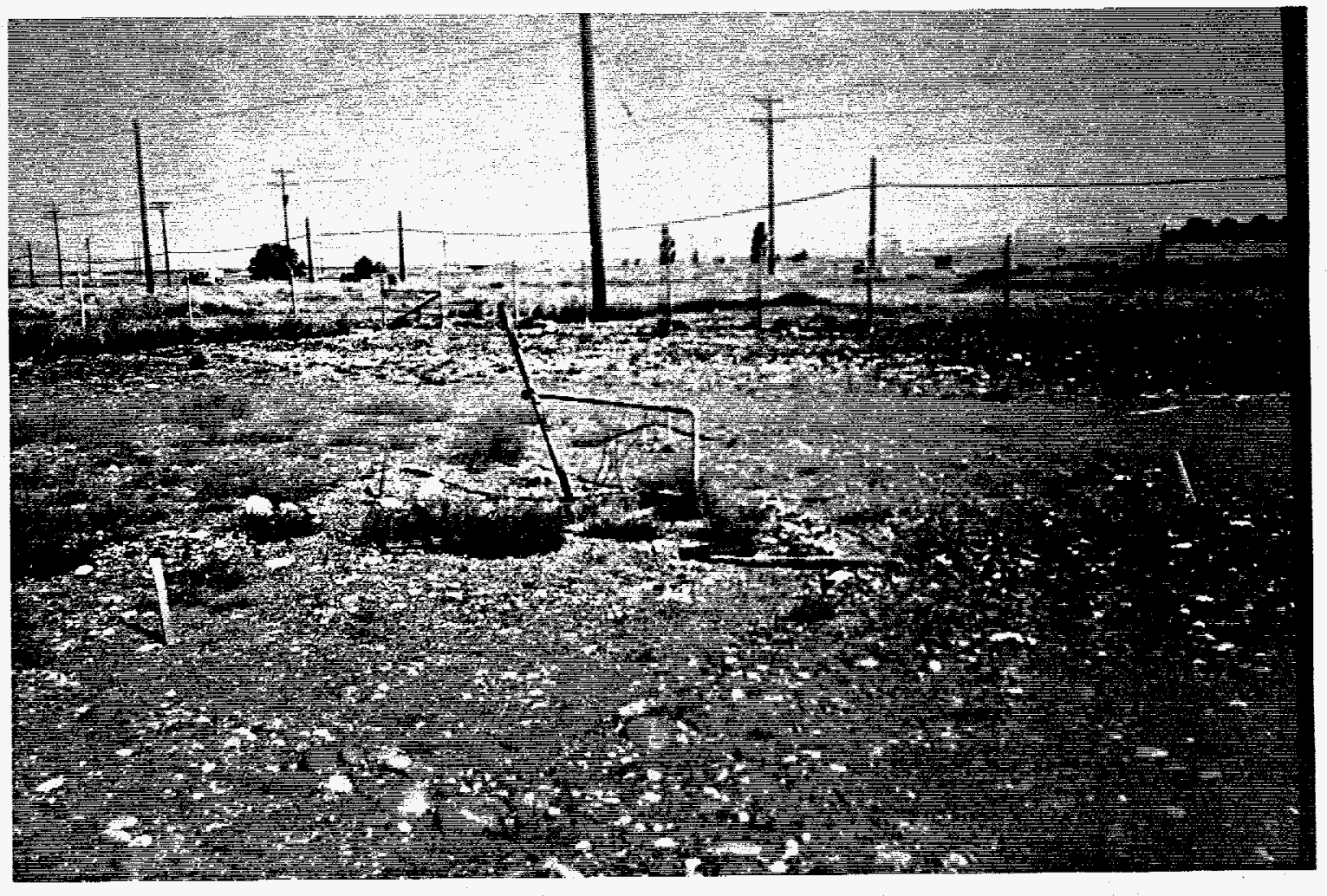

Photograph 22: JA Jones Steam P7ant location at north end of property showing the piping that was not removed 





4.6. and

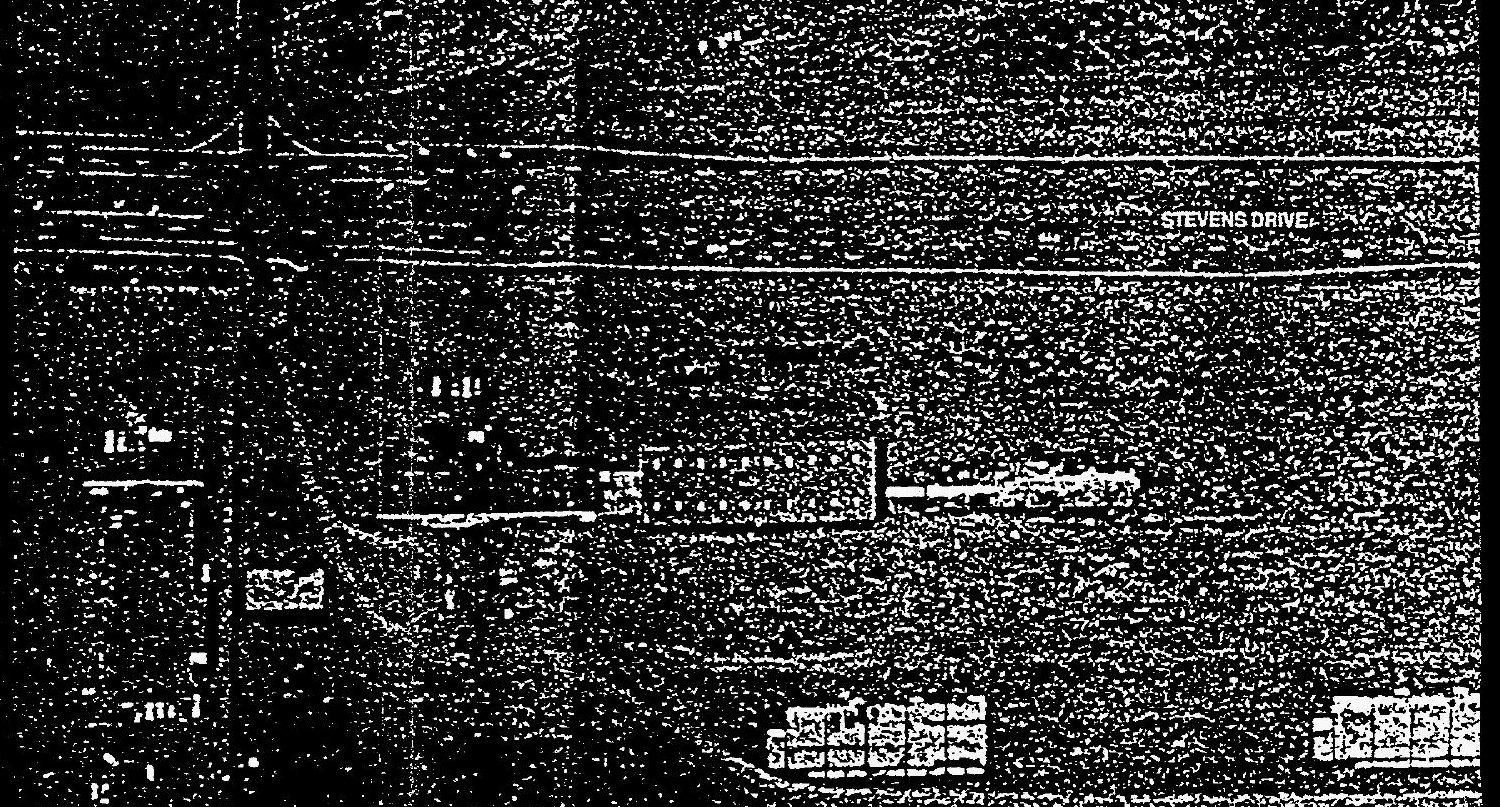

Lis:
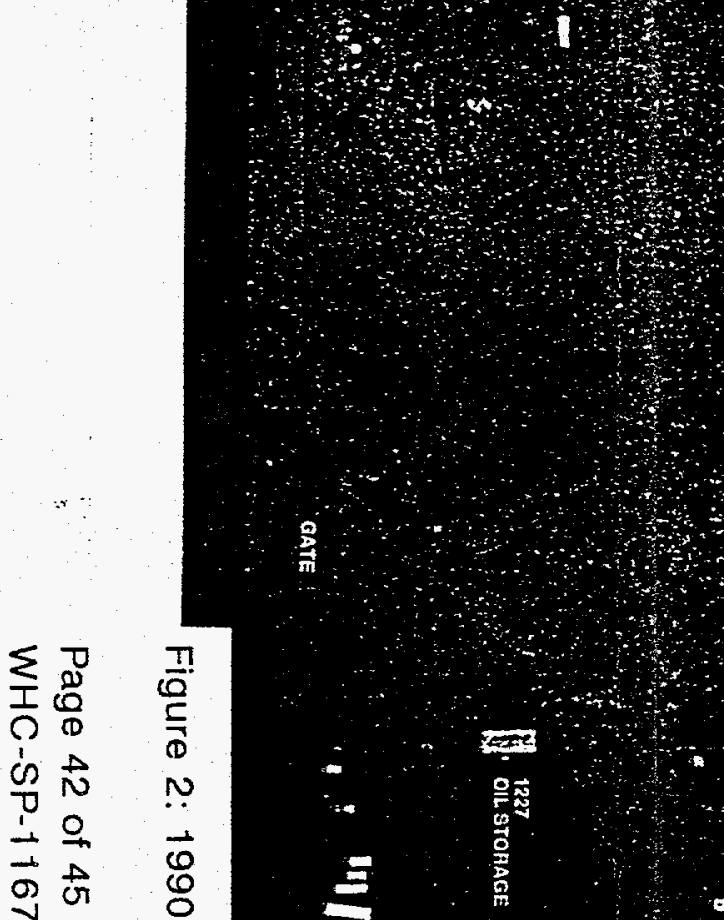

疍

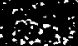

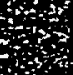
H
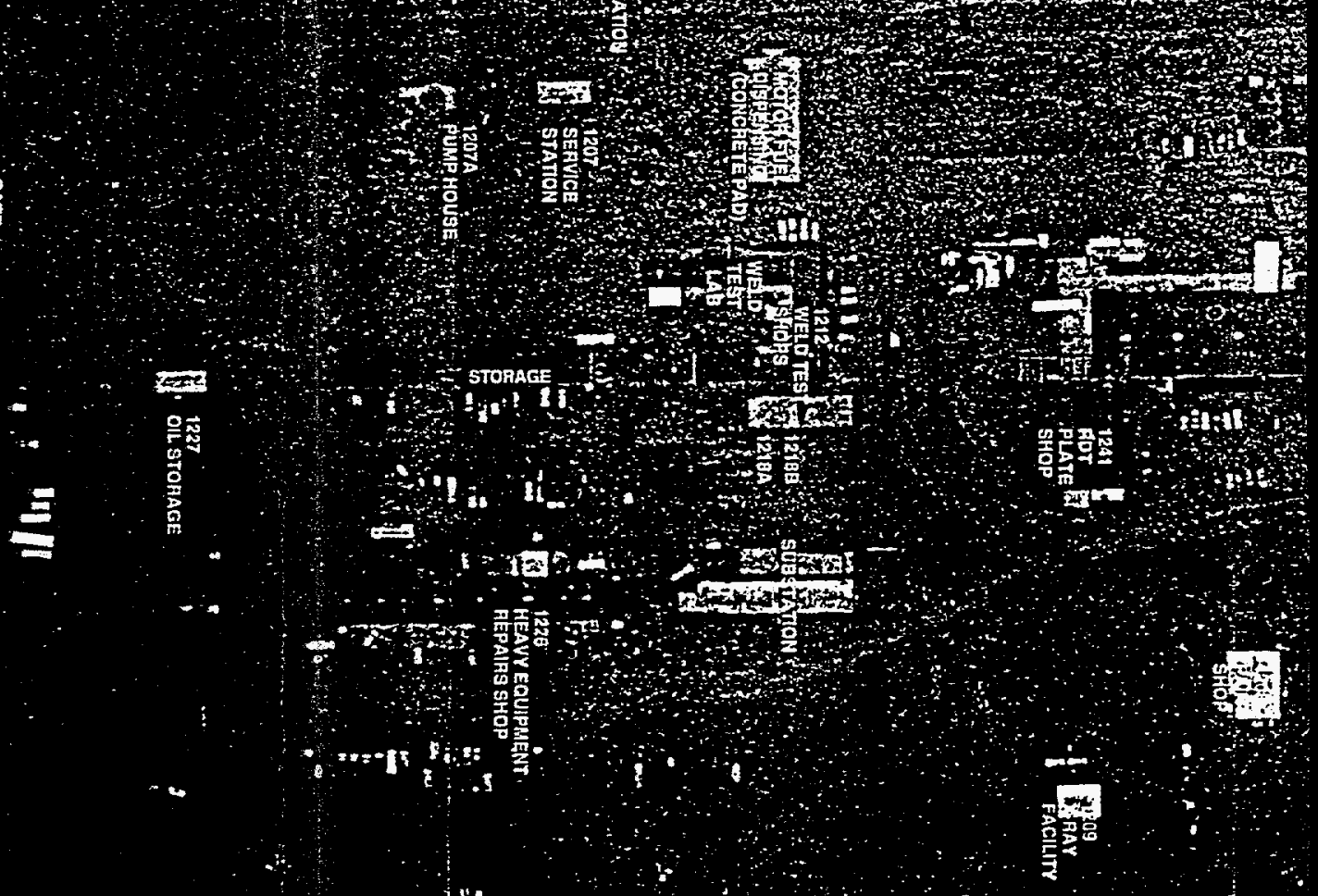


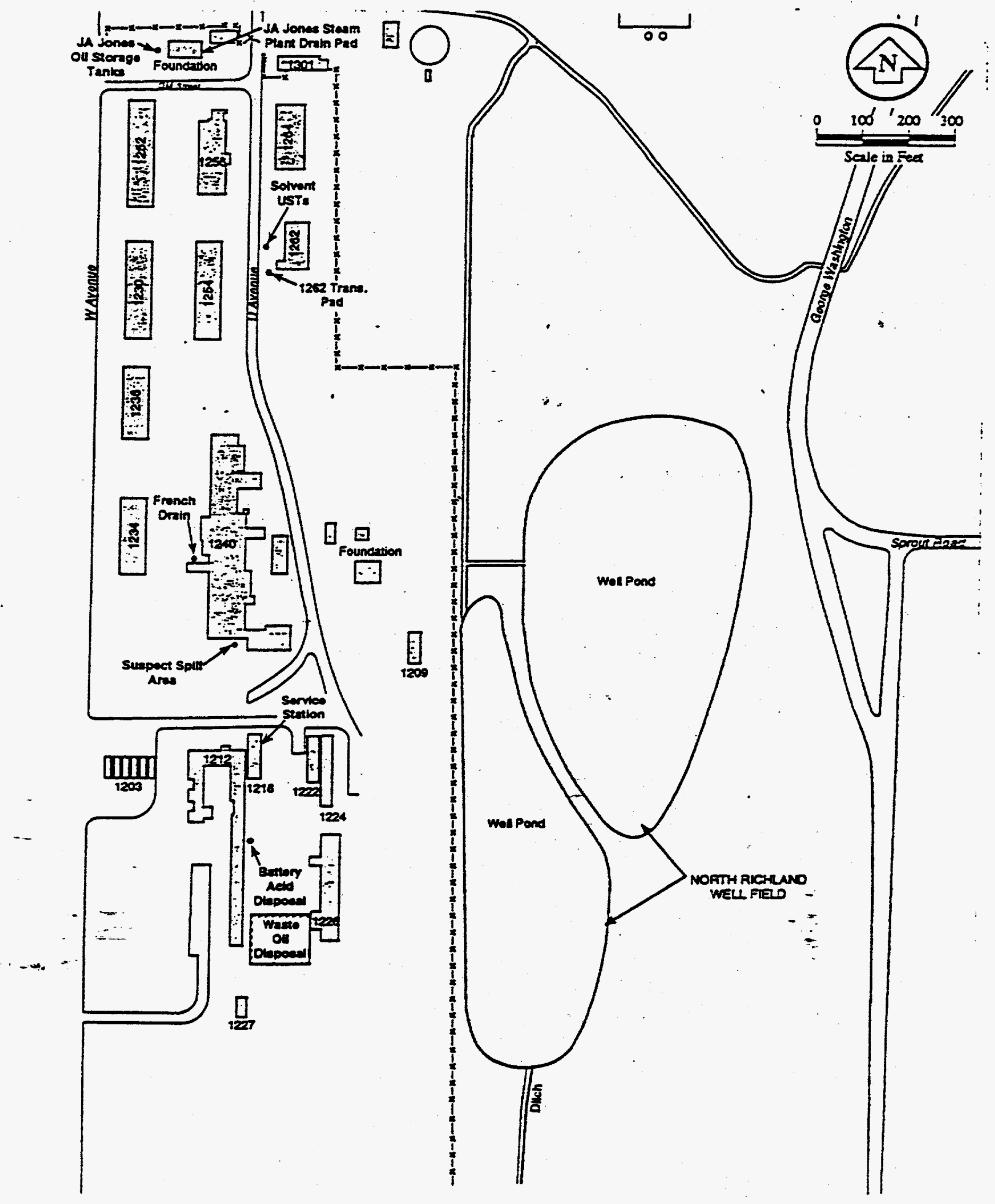

Figure 3: Location of WMUs in Operable Unit 1100-EM-3

Page 43 of 45

WHC-SP-1167 


\section{$\leftarrow \mathbf{N}$}



LEGEND

15,000 GAL. UNLEADED GAS

15,000 GAL. (USED FOR UMLEADED GAS IN PAST)

15,000 GAL. REGULAR GAS

15,000 GAL. REGULAR GAS

20,000 GAL. DIESEL

10,000 GAL. SODIUM LIGNOSULFONATE

10,000 GAL. UNLEADED GAS

10,000 GAL. UNLEADED GAS

10,000 GAL. UNLEADED GAS

10,000 GAL. DIESEL

12,500 GAL. DIESEL

LOCATION OF UNDERGROUND STORAGE TANKS \#1 THRU \#13
Figure 5: Location of USTS Removed by WHC/ICF KH

Page 45 of 45 